\title{
The Multiple Spanish elections of April and May 2019: the impact of territorial and left-right polarisation
}

Pablo Simón

\begin{abstract}
This article analyses the 2019 local, regional, European and April general elections in Spain. The constitutional crisis in Catalonia in 2017, the motion of no-confidence leading to the new Socialist government and the emergence of a radical right-wing party, VOX, all led to Spanish politics becoming more polarised. This paper also discusses polarisation from both the left-right and the territorial perspectives, intimately linked in Spain both for historical reasons but also because of agency decisions during the period analysed. Finally, the article shows the electoral results, government formation processes and political implications of polarisation in a non-institutionalised party system.
\end{abstract}

Keywords: Spain; Elections; Catalonia question, VOX; PSOE; PP; regional election; European Parliament Election

In 2019 multiple elections were held in Spain: European, regional and local elections, as well as two general elections. These elections were exceptional for different reasons: they not only showed record levels of fragmentation, but also saw the appearance for the first time of a radical right-wing party, VOX. Moreover, the elections did not take place at the end of any ordinary legislative term. In October 2017 there had been a secession attempt in Catalonia that had caused a major constitutional crisis and, in May 2018, for the first time in recent history, there was a change of government during a parliamentary term. The Spanish Socialist Worker's Party (PSOE) had been successful in winning a vote of no-confidence that allowed Pedro Sánchez to replace Mariano Rajoy as Prime Minister.

The 2019 electoral cycle was marked by these specific features and, consequently, the Spanish party system underwent significant changes. It was not only the appearance of a new radical right-wing party that changed it; also a completely new dynamic took hold in which the state-wide five party system became a two-bloc system; Unidas Podemos (United We Can - UP) and the PSOE on the left, and the Partido Popular (Popular Party - PP), Ciudadanos (Citizens - Cs) and VOX on the right.

This paper discusses all these features and how the lack of an institutionalised party system (Mainwaring \& Zoco, 2007) created incentives for polarisation in Spain. On the one hand were the potential ethnic outbidding among pro-independence parties in Catalonia (Barrio \& Rodríguez-Teruel, 2017) and the trial of their leaders for sedition, along with the electoral aims of the right-wing state-wide parties, which all strongly defend Spanish unity. On the other hand was the left-right differentiation of the ideological blocs, making any national government formation process more conditioned by the pro-independence parties (for a left-wing majority) and by VOX (in the case of a right-wing majority).

Additionally, the paper examines the increase in polarisation regarding both the left-right and the territorial axes, as well as their saliency. The literature points to the leftright and the territorial dimensions as being mutually dependent in Spain since, for historical reasons, the Spanish right has presented itself as opposed to decentralisation while peripherical nationalism has found more support on the left (Dinas 2012; Galais \& 
Serrano 2019). As will be discussed, the context of electoral fragmentation and volatility has caused polarisation in both dimensions to evolve side by side.

However, it is impossible to explain polarisation without considering the context prior to the elections. In this sense, the new PSOE leadership, the application of article 155 of the Constitution, the change in the PP leadership, the rise of VOX in snap elections in Andalusia and Ciudadanos' decision to veto any agreement with the PSOE all opened the door to a polarised election. The paper also explores how it conditioned the formation of two blocs and stresses one crucial novelty when compared with the 2016 general election: now the PSOE had firmly re-established its role as the leading party on the left, while the fragmentation and competition was between the right-wing parties.

The general election held on 28 April 2019 (referred to informally as $28 \mathrm{~A}$ in Spanish) resulted in a PSOE victory (123 seats) and in important losses for the PP (66 seats). Then came Ciudadanos (57 seats), UP (42 seats) and VOX ( 23 seats). There was no majority possible without the PSOE, while the sum of the PSOE's and UP's 165 seats was insufficient to form a government without the vote/abstention of regionalist/proindependence parties. The European, the 12 regional and the local elections were held together one month later, on 26 May (referred to as 26M). The PSOE came out as the party with most votes in the European Parliament and in 10 of the 12 regions; the PSOE also won power in three additional Autonomous Communities (Navarra, the Canary Islands and La Rioja). The only change was that on this occasion, in contrast to the 2015 regional elections, coalition governments were formed everywhere.

The paper is structured with the next section presenting the context before the elections and section three discussing polarisation and its role during the electoral campaign. Section four presents the results of the general, European, regional and local elections in Spain. This is followed by a section which discusses the future implications of polarisation. The last section concludes.

\section{The path towards a polarised election}

In the space of three years, from 2016 to 2019, striking and unprecedented changes took place in the Spanish political landscape. On the one hand, a constitutional challenge took place between state-wide and Catalan institutions that led to an independence referendum being held on 1 October 2017 . This provoked the intervention of the national police forces, that raided several polling stations and injured voters, the proclamation of an independent republic in Catalonia, and the activation of Article 155 of the Spanish Constitution, resulting in the central government closing down the Catalan government and calling new regional elections.

On the other hand, in June 2018 the PSOE registered a successful motion of noconfidence against the government of Mariano Rajoy with the support of Podemos and the regional/nationalist parties. It was under the new Socialist minority government that VOX emerged in Andalusian regional elections and it was Pedro Sánchez, the new Prime Minister, who took the decision to call general elections on 28 April. This section recounts the events that took place from the election of Mariano Rajoy in October 2016 to the electoral campaign of 2019.

\section{The government of Mariano Rajoy}

Mariano Rajoy, then leader of the Popular Party, was elected Prime Minister on 29 October 2016. This took place after several changes in Spanish politics (Simón 2016). Firstly, Rajoy was elected after a second general election, on 26 June, that was held because the Spanish political parties were not able to reach an agreement after the 
December 2015 general election. Secondly, his government had the narrowest margin of seats since the restoration of democracy: a single party minority cabinet with only 137 of 350 seats (Table 1). The Popular Party governed with the parliamentary support of the liberal centre-right party Ciudadanos (32 seats) and the regionalist party Coalición Canaria ( 1 one seat) and its government was six votes short of the absolute majority in Congress.

Finally, for the first time in modern democratic history, the Spanish PM was elected thanks to the abstention of the main opposition party, in this case the PSOE. This abstention entailed an internal party struggle that ended with the resignation of its leader, Pedro Sánchez, and the putting in place of a caretaker committee that ran the party for the following months. Thus, political deadlock in Spain was eventually broken after a year-long process, a second general election and the PSOE's internally divisive abstention (Cruz 2016).

Table 1 Congreso de los Diputados after the 2016 general election

\begin{tabular}{ccc}
\hline Right-wing state-wide parties & $\begin{array}{l}\text { Regional/ independentist } \\
\text { parties }\end{array}$ & Left-wing state-wide partie \\
\hline PP (137 seats) & ERC (9 seats) & PSOE (84 seats) \\
Cs (32 seats) & PDeCAT (8 seats) & UP (71 seats $)$ \\
& PNV (5 seats) \\
Bildu (2 seats $)$ & \\
CC (1 seat) \\
NC (1 seat)
\end{tabular}

Source: Congreso de los Diputados

There were actually two possible alternative majorities in the Congress. On the one hand, one made up of the 170 seats of the Popular Party, Ciudadanos and Coalición Canaria. Those parties could reach an absolute majority of 176 with the five seats of the PNV (Partido Nacionalista Vasco) and a single MP from Nueva Canarias (a regional party in a coalition with the Socialists). This majority allowed the government, for example, to approve the budget in 2017 (Garea 2017). The second possible majority was the one made up of the PSOE (85 seats), Unidos Podemos (the left-wing coalition of Podemos and United Left, 71 seats), the pro-independence Catalan parties Esquerra Republicana (ERC- 9 seats) and PDeCAT (7 seats), the Basque Nationalist Party (PNV - 5 seats) and the pro-independence Basque party Bildu (2 seats). However, this second option was impossible since the PSOE had ruled out any negotiations with the Catalan secessionist parties, especially since an unauthorised referendum was being prepared by the Generalitat of Catalonia (Infolibre 2016).

Two events took place after the election of Rajoy as PM. The first was the election to choose a new PSOE leader to replace the caretaker committee (PSOE, 2017). In January 2017, Patxi López, former president of the Basque Country and the Congress, announced that he would run. He gained the backing of some party figures close to Sánchez, but not much support generally. At the end of that month Pedro Sánchez also announced his intention to run again. With little infrastructure and almost no organic support, Sánchez based his campaign on a more left-wing platform, shunning the 
traditional Socialist establishment and criticising the abstention of the PSOE that had allowed the formation of the 2016 Popular Party government (Limón 2017). Susana Díaz, president of Andalusia, waited until March to present her candidacy and was supported by most of the top party figures and former Socialist presidents (Luna 2017). She was considered the front-runner of the competition.

The party leader was elected by a one member one vote system (Ramiro 2016). There were 187,949 registered party members. To compete at all, a candidate needs to be endorsed by five per cent of the membership, so this stage of vote collection tends to be considered the first round of the contest. The candidates were registered on 4 May and there was practically a tie between Díaz $(60,231)$ and Sánchez $(53,692)$, with Patxi López only registering the minimum number of endorsements required $(12,000)$. The polls also indicated that in almost all cases Sánchez was the favoured leader among Socialist voters (Romero 2017). Voting day was 21 May and Pedro Sánchez obtained 74,805 votes (50.26 per cent), Susana Díaz 59,392 votes (39.9 per cent), and Patxi López 14,652 votes (9.84 per cent). In this way, Pedro Sánchez was reinstated as leader of the PSOE (Díez 2017).

The second important event was a vote of no-confidence against Mariano Rajoy's government. According to article 113 of the Spanish Constitution, this can only be proposed with a minimum of 35 MPs supporting it (Colomer, 2020). The motion also needs to present an alternative candidate for PM and, to be successful, the requisite is an absolute majority. Podemos registered the vote of no-confidence and Pablo Iglesias, its leader, presented himself as candidate. The vote was announced on 27 April 2017 after the eruption of a corruption scandal that affected the government. The intention of Podemos was to stake its claim as the main opposition party and to influence the PSOE's internal processes. The vote of no-confidence was held on 14 June. Podemos gained the support of its own group, ERC and Bildu (82 votes), the rest of the parties voted against it while the PSOE, PDeCAT, PNV and Nueva Canarias abstained (Cortizo 2017). As a consequence, Rajoy's government continued in place. However, Podemos and the PSOE agreed to keep talks open to build a majority in Congress.

\section{The Catalan bid for independence}

From 2012 to 2015, the Catalan and Spanish institutions clashed over the Catalans' demands to organise an official independence referendum. The Catalan parliament demanded a referendum on self-determination, with the national parliament refusing on the grounds that the Spanish Constitution did not allow it. ${ }^{1}$ As a result, and after a nonbinding consultation 9 November 2014, the regional prime minister, Artur Mas, called an election on 27 September 2015, trying to frame it as a de facto referendum on independence (Orriols \& Rodon 2016).

The pro-independence parties Junts pel Sí, JxS - Together for Yes, a coalition of Convergència Democràtica de Catalunya (CDC) and ERC - and the left-wing secessionist Candidatura d'Unitat Popular (CUP) won a majority of seats in the Catalan Parliament (72 of $135 \mathrm{MPs}$ ) but not an absolute majority of votes (48 per cent). Despite winning the election, JxS had six seats fewer than the absolute majority and needed support from the CUP. However, the CUP was strongly committed to not re-electing President Artur Mas, considering him the main culprit for previous budget cuts (De Diego, 2015). After tough negotiations, Artur Mas stepped aside and the Mayor of Girona, Carles Puigdemont, was made head of the Catalan government (García 2016). The new cabinet soon confirmed an 18-month secessionist roadmap, during which the Catalan government would seek to create structures for an independent state (such as a social

\footnotetext{
${ }^{1}$ Article 2 of the Spanish Constitution states that "[the Constitution] is based on the indissoluble unity of the Spanish Nation, the common and indivisible homeland of all Spaniards; it recognises and guarantees the right to self-government of the nationalities and regions of which it is composed and the solidarity among them all."
} 
security system and a public bank), and eventually hold a referendum on a new Catalan constitution. The novelty this time was that the Generalitat decided to proceed unilaterally by organising a binding referendum on self-determination.

On 9 June 2017, Puigdemont announced that the referendum would take place on 1 October after a cabinet reshuffle to expel the members that disagreed with it. The question would be 'Do you want Catalonia to become an independent state in the form of a republic? Yes or No' and it would be binding (Cordero 2017). The Catalan Parliament, in its 6 and 7 September sessions, approved the Referendum Law and the Juridical Transition and Foundation of the Catalan Republic Law with only the support of the pro-independence parties. This second law guaranteed a new legal framework for the administration and public services during Catalonia's transition to an independent country in the case of the referendum result being affirmative. The laws were approved thanks to a parliamentary procedural reform that allowed a fast-track discussion. This reform, the previous laws and the decree that called for the referendum were overturned by the Spanish Constitutional Court. Consequently, the referendum was declared suspended and, later, not legal (Fundación Alternativas 2018, p. 163)

Ten days later, the Spanish government began controlling all payments made by the Catalan government to prevent any financing of the referendum. On 20 September, the Spanish Guardia Civil arrested 14 senior officials involved in planning the referendum, raided printing companies to confiscate ballots and closed down various related websites (Carranco 2017). That day, a crowd gathered by Òmnium Cultural and Assamblea Nacional Catalana (ANC), the two main pro-independence grassroots associations involved in the referendum, surrounded the Catalan Ministry of Economy and vandalised three vehicles, preventing police officers from leaving the building they were searching until several hours later (Olmo 2018). The Spanish national police were sent reinforcements by the national government to prevent the referendum taking place, while tension in the mass demonstrations also heightened. On 22 September the Constitutional Court dissolved the Electoral Commission that was to supervise the referendum and disallowed any related campaigning. Eventually the Generalitat used an internet census. The activist and pro-independence associations concealed the ballot boxes and camped out in different town halls and schools to protect the voting stations (Salles 2017).

The day of the referendum, 1 October, saw the intervention of the national police forces, that raided several polling stations and injured voters (Cetrà et al. 2018). The Spanish vice-president, Sáenz de Santamaria considered the referendum aborted but voting took place for the rest of the day. According to the organisers, the result was a turnout of 43 per cent with 92 per cent of people voting for independence. That night, Mr. Puigdemont said he would act according to the results, despite the Spanish government insisting that the result was null and void. On 3 October, the King of Spain intervened on television and declared that 'in light of this extremely serious situation (...) the legitimate powers of the state have the responsibility of guaranteeing constitutional order and the normal functioning of the institutions, the validity of the rule of law and Catalonia's selfgovernment, based on the Constitution and its Statute of Autonomy' (Santos \& Sierra 2018). Over the following days, thousands of citizens in Spain and Catalonia put up flags on their balconies in a signal of support for the unity of Spain.

The political implications of this constitutional crisis were twofold. On the one hand, on 10 October, Puigdemont proclaimed Catalonia independent, but suspended independence immediately in order to enter into dialogue with the central government (Puente 2017). The response of the government was to activate Article 155 of the Spanish Constitution. This article allows the temporary suspension of a regional government when it is considered that it 'deviates from the general will'. This requires notifying the regional government in advance and the approval of the Spanish Senate by absolute majority; here the Popular Party would have met the requirement by itself, but the PSOE and Ciudadanos also added their support. The procedure ended on 27 October, when the unilateral declaration of independence was finally approved by the 
Catalan Parliament (Dominguez \& Alberola 2017). Prime Minister Mariano Rajoy announced the dissolution of the Catalan government and parliament and called an election for 21 December.

Another side of the crisis entailed the immediate prosecution by the Supreme Court of Catalan pro-independence leaders on charges of rebellion and sedition. Puigdemont fled to Belgium with other regional ministers, while the leader of ERC, Oriol Junqueras, the leaders of Òmnium and ANC, Jordi Sánchez and Jordi Cuixart, among others, were imprisoned (Pinheiro 2017). The trial lasted months until the final sentencing in October 2019, creating tension and protests against the court's resolutions.

Turnout in the 21 December Catalan election was 79 per cent. The results were a new victory in number of seats for the pro-independence parties (66 over 135 seats), this time with Junts per Catalunya (JxC, the former CDC) and ERC competing separately, and still needing the 4 CUP MPs to reach an absolute majority. The most voted-for single party was Ciudadanos, a party with a clear anti-independence platform (Rodríguez-Teruel \& Barrio 2016), but it was unable to forge a majority in the regional parliament. Forming a government was delayed due to attempts to re-elect either Puigdemont in absentia, Jordi Sánchez, the imprisoned leader of ANC, or the government spokesman, Jordi Turull, imprisoned the day after this first investiture vote in which he did not obtain a majority (Quitian 2018).

Finally, on 12 May, the pro-independence parties nominated Quim Torra for regional president. He was elected on 14 May after a second vote, in which only a simple majority was required and thanks to the CUP abstaining. Since a new regional government was in place, Article 155 was lifted (García, 2018a). Nevertheless, Mr. Torra insisted that he would be loyal to the popular mandate of 1 October and would denounce the unprecedented repressive situation in Catalonia.

\section{A new Socialist government}

On 24 May 2018, in a trial known as Gürtel case, the National Court confirmed that an illegal financing structure for the Popular Party had existed since 1989. The Court also ruled that Mariano Rajoy, a witness during the trial, had not been truthful (Carpio 2018). This corruption scandal was already well known and had already had some political consequences, such as the emergence of the new parties Podemos and Ciudadanos in 2014 (Orriols \& Cordero 2016), but this was the first time a court had pronounced a sentence that condemned the PP as an organisation. As a reaction to this, on 25 May the PSOE registered a vote of no-confidence against Mariano Rajoy, and Pedro Sánchez presented himself as the alternative candidate. His main argument was that it was necessary to restore 'democratic normality' due the government not accepting its responsibilities and then, to call new elections (Nieto 2018).

Ciudadanos also withdrew its support from the PP government and called for early elections. The PSOE accepted this proposal but only if Cs supported Pedro Sánchez's motion. Ciudadanos declined and insisted that Mariano Rajoy resign. The vote was scheduled for 31 May and 1 June. Unidos Podemos gave their support to the motion of no-confidence. After secret negotiations, ERC and PDeCAT, both Catalan proindependence parties, also gave their support to the motion (Martin 2018) ${ }^{2}$. At that point, Rajoy recognised that he had lost control and agreed to call elections in late 2018. But it was too late for such a decision. The only votes remaining to ensure the success of the vote of no-confidence were those of the decisive 5 PNV MPs who, at that time, were negotiating the 2018 budget with the PP. Eventually, on 31 May, the Basque Nationalist Party agreed to support the PSOE in exchange for some guarantees about budgetary issues (Sierra \& Marmol 2018). With 180 votes and an alliance that would have been impossible in 2016, Pedro Sánchez became Prime Minister of Spain.

\footnotetext{
${ }^{2}$ Compromis, Bildu and Nueva Canarias also agreed to support the vote against Rajoy.
} 
This situation was unprecedented in the recent history of Spain. It was the first time a head of the government was not a member of the national parliament and was the leader of the second party in the Congress. Sánchez, immediately after the motion, formed a minority PSOE government with the support of only $84 \mathrm{MPs}$, the lowest parliamentary support ever in recent democratic history. Nevertheless, the arrival of Pedro Sánchez ushered in an initial honeymoon period in which the Socialists led in the polls (Cruz 2018). The government launched a programme of social policies (i.e. restoring healthcare to undocumented immigrants, increasing the minimum wage) and symbolic gestures (i.e. removing Franco's body from its mausoleum or accepting Aquarius, the humanitarian ship rejected by Italy) (Gil 2019). Nevertheless, the vote of no-confidence did not mean that the new Socialist government had the support of the parties that had overthrown Rajoy's government. Therefore, due the lack of a parliamentary majority, the government used decrees to pass most of its measures.

Mariano Rajoy resigned as leader of the Popular Party. This meant, for the first time, a contest for the leadership of the PP. Its internal rules call for a two-stage process (PP 2018). First, party members can vote for any of the candidates. If a candidate obtains 50 per cent of the votes or a 15-point difference from the second candidate, s/he is elected. If this does not happen, in the second stage, party delegates will choose the leader in a general congress, choosing between the two candidates who polled the highest number of votes in the first round. There were six candidates in the first round and the final contest was between Soraya Sáenz de Santamaria, Mariano Rajoy's former vice-president, and Pablo Casado, his head of communications. Casado was the winner, garnering 57 per cent of the votes. He was considered the more right-wing candidate (Junquera 2018).

In October 2018, VOX made its first appearance in the media. VOX is a radical right-wing party with a political ideology firmly grounded in authoritarian conservatism and nationalism. It advocates policy positions that include opposition to same-sex marriage, opposition to abortion, to gender quotas and to domestic violence protection regulations. It shares some policies with other radical right-wing parties in Europe but has a more neo-conservative slant (Turnbull-Dugarte 2019). Echoing parties with a similar ideological and populist tone (Mudde 2009), VOX also takes a very hard line on immigration, advocating for the deportation of all undocumented immigrants and the end to social policies that allegedly serve to attract them. On the territorial question, this party promotes policies that reflect both its preference for authoritarianism and its focus on Spanish nationalism, calling for the abolition of all the Autonomous Communities and closedown the Catalan government indefinitely. In a context of great polarisation regarding territorial issues, this party was in a good position to present a platform that could take this hard line and attract right-wing voters.

On 2 December there were regional elections in Andalusia, called three months ahead of schedule by the Socialist regional president, Susana Díaz (Martín-Arroyo, 2018). Díaz's call was widely viewed as a political gamble, aiming to capitalise on the PSOE's political momentum now that they had taken over the national executive, but also aiming to avoid territorial polarisation. The results were not anticipated by the polls. Both the PSOE (dropping from 47 to 33 seats) and Adelante Andalucía (Ahead Andalusia, the coalition made up of Podemos and United Left, dropping from 20 to 17 seats) fell short of the majority. Consequently, the mainstream right-wing parties, the Popular Party (26 seats) and Ciudadanos (21 seats) had the opportunity to form a minority coalition thanks to the external support of radical right-wing VOX, with a surprising 10.5 per cent of votes and 12 seats. This was the first time the region was not governed by the Socialists since the restoration of democracy (Tortosa 2019).

Recent research indicates that, while other radical right-wing parties in Europe gained their support from welfare chauvinism strategies, this was not the case of VOX. The party gained voters mainly from the Popular Party and Ciudadanos. Decisions to vote for this party at that time were linked, not to its position on immigration but rather to its position on the territorial crisis (Turnbull-Dugarte, 2019). The main driver for VOX 
voters in Andalusia, especially among the right-wing voters, was its declared aim of reducing the Autonomous Communities' devolved powers. This had the effect of pushig VOX's competitors on the right towards its position on territorial issues in order to avoid major electoral losses

\section{The path to the April general elections}

According to the calendar fixed by Spanish law, regional, local and European elections were to be held on 26 May 2019 (informally labelled in Spain as 26M), but there were still doubts about the date of the general election. Pedro Sánchez, with very slim parliamentary support, had no more than two years until the ordinary legislative term was up. According to the empirical evidence, in parliamentary systems it is more probable to call for a strategic election when there is a single minority government, the economic situation is good and the opposition is divided (Riera 2015). This situation met all those requirements, and the doubt was whether the general election would be called after, before or on the same date as the European, regional and local elections: 26 May.

There were two crucial strategic considerations for Pedro Sánchez to ponder. On the one hand, the potential contamination effect that can be created across elections (Guinjoan 2016). A general election is considered a first order election and, therefore, it could affect the propensity for voting for the same party on the same day; if it is earlier, it can create a honeymoon effect that benefits the winning party. On the other hand, the Spanish national electoral system is far less proportional than the regional and local ones (Penadés \& Santiuste 2013). Consequently, fragmentation could entail more wasted votes in the national arena than in other arenas. This could have been advantageous for the PSOE since it continued to be in first place and could benefit from left-wing voters casting their ballots strategically. At the same time, the continued increase in support for VOX divided the right-wing party supply, making the parties of the right-wing bloc less efficient in translating votes into seats.

The last budget approved in Spain had been drawn up by the former executive, made up of the PP and Ciudadanos. Consequently, the PSOE government declared that unless it could approve its own budget in 2019, the legislative term would be reduced, and they would call elections. The PSOE and UP agreed on a basic budget on 11 October, but to be approved it required the support of the pro-independence parties. On 21 December, under tight security measures, the national executive held a cabinet meeting in Barcelona (García 2018b). A meeting between Pedro Sánchez and Quim Torra, the president of Generalitat, also took place. They jointly wrote a document, the 'Declaración de Pedralbes' about the necessity of finding a democratic answer to the Catalan political conflict, one that respected the rule of law (Varela 2018).

On 14 January the budget was formally registered in the Congress. But two weeks later, a crisis erupted. On 5 February news broke that the national government would accept a formal mediator to help in talks between Catalan and Spanish parties (Pinar 2019). This created consternation and criticism both from the parties in opposition and from the socialist regional leaders; it was considered that the fact of providing a mediator recognised the equal status of the national and the Catalan governments (Castro, 2019). This came at the same time as the registration, just two days earlier, of amendments to the budget by ERC and, later, by PDeCAT. As a consequence of this crisis, the national government considered that relations with the pro-independence parties had broken down, and the budget finally failed to pass (Mayo 2019).

The opposition parties PP, Ciudadanos and VOX organised a demonstration on 10 February in Colon Square in Madrid. They were protesting against what they called the Spanish government's 'surrender to secessionism' and called for immediate elections (Sanz \& Sanmartín, 2019). Despite the absence of official logos, the picture of the leaders of the three parties together was seen as a signal of a potential coalition government against Pedro Sánchez, like the one in Andalusia. Moreover, this demonstration also entailed a change in Ciudadanos' strategy: the party had previously 
avoided being identified in any agreement with radical right-wing VOX (González 2019). In reaction, five days later, PM Pedro Sánchez called for general elections to be held on 28 April (28A). He alleged that he 'could not continue with the budget of the previous government', he called for dialogue 'within the Constitution' and criticised the Colon march as 'exclusionary vision of Spain' (Cue 2019). A few days later, the Socialist president of the Comunitat Valenciana, Ximo Puig, decided to bring forward regional elections to take place on the same day as the general election.

\section{The role of polarisation in elections}

The extent to which party policy alternatives are perceived as different by the electorate is crucial on issue voting (Sánchez-Cuenca \& Dinas 2016). Thus, in addition to the existence and salience of a political issue, party system polarisation is relevant in making vote decisions. Moreover, it has been proved that, in the European context, this differentiation between political parties is important in explaining ideological voting (Lachat, 2008). Party system polarisation heightens voters' perceptions of what is at stake in elections. If parties present a policy convergence, it does not matter the winner of the election. Conversely, if polarisation about an issue is high, it heightens voters' awareness of the different alternatives (Knutsen \& Kumlin 2005).

Party polarisation is a dimension that differs from the number of parties in a country. In some multiparty systems, competition can by translated into a polarised pluralism, with elements that the traditional literature has linked to the erosion of the political system legitimacy (Sartori 1976). However, and although a minimum dispersion in parties' policy platforms are required in any competitive democratic system, multipartyism can also be related to centripetal forces (Evans 2002). Thus, the determinants of polarisation are not (only) linked with the number of alternatives present. Institutional settings, such as the parliamentary/presidential nature of the system or regional/federal models, have been proven to affect voters' decisions. For example, when voter preferences are watered down by power-sharing, this can be compensated by people voting for more extreme positions than their own (Kedar 2005).

However, party system polarisation is mainly contextual. In this sense, three elements can foster ideological variance: heterogeneity in society, conflict inevitability and uncertainty (Downs 1957; Sartori 2005). It is this third component which has received most attention. In order to make ideology work as a useful shortcut for voters and to prevent parties from being squeezed by other parties, in contexts of changing electoral patterns it makes sense to diverge in terms of policy platforms. Thus, despite continuing to consider the median voter's position, electoral uncertainty increases polarisation (Pardos-Prado \& Dinas 2010).

The specialised literature has devoted significant attention to conceptualising and discussing how polarisation should be measured (see Lachat 2008). On an aggregate level, the standard procedure to measure party polarisation is to use the average of individuals' perceived party positions; this, in general, has been restricted to the left-right ideological scale. In this sense, one of the most common measures is the one by Dalton (2008), that considers both party distribution along the ideological dimension according to voters' perceptions and also their vote share:

$$
P I=\sqrt{\sum\left(\text { party vote } \text { share }_{i}\right) *\left(\frac{\left[\text { party } L-R \text { score }_{i}-\text { party system average } L-R \text { score }\right]}{5}\right)^{2}}
$$

Where $i$ represents the individual parties and the L-R score refers to the left-right scale in the continuum. This index is easily comparable across countries and over time, and is also equivalent to a measure of the standard deviation of a distribution. To reflect the Spanish case, the traditional left-right scale measured by the Spanish Centro de Investigaciones Sociológicas (CIS) from 1 (extreme left) to 10 (extreme right) has been 
used. The result is an index that ranges from 0 , where all the parties occupy the same position on the left-right scale, to 10, where all the parties are split between the two extremes.

Nevertheless, politics is rarely based on one single issue of competition. In fact, together with economic issues, dimensions including cultural politics, the dimension GAL (green/ libertarian/ alternative) TAN (traditional, authoritarian, nationalism) has also considered as playing a role (Hooghe \& Marks 2009). However, its saliency is linked with the historical roots of each society. The literature points out that the historical religious divide predicts the extent to which this cultural dimension presents the distinctiveness of the left-right axis. It is in mostly Catholic societies where both dimensions tend to be more associated: the left is perceived as more liberal and open while the right is more traditional and nationalistic (Rovny \& Polk 2018). This is the case in Spain, where economic and noneconomic conflicts are more unified (ibid, p. 21). In fact, during the recent economic crisis, Southern European countries did not politicise European issues in a cultural-identarian manner, but reflected opposition to austerity and democratic renewal issues by using the traditional left-right dimension (Hutter et al 2018).

However, in the case of Spain, politics has been marked by the presence of nonstate-wide parties. As a consequence, the competition space has been considered as bidimensional; politics is not only determined by the left-right divide but also by nationalperipheral identities (Linz \& Montero 1999). In fact, it has been proven that the territorial issue, linked with identity and preferences for decentralisation, plays a role in the position that citizens and parties adopt (Sánchez-Cuenca \& Dinas 2012). Despite that, the two dimensions are not orthogonal due to the existence of a 'left-dominated nationalism' (Dinas 2012). There are historical roots that link peripheral nationalism with the left in Spain (since the opposition of both left-wing and regional nationalist parties to the Franco Regime), with the two dimensions being intimately linked. Therefore, Spanish nationalism tends to be identified with the right, and regional nationalism with the left, which also explains why conservative Catalan or Basque regional parties tend to be seen as more progressive.

Nevertheless, in addition to historical reasons, party competition plays a role in emphasising ideological differences: the frame of the territorial question is contingent on the issues discussed in each campaign or context (Sánchez-Cuenca \& Dinas 2012). Therefore, territorial polarisation in Spain can be measured in a similar fashion to the classical economic dimension. Considering the spatial models that are applied to the L$\mathrm{R}$ scale, the position of voters and parties has been considered using the continuous CIS index that ranges from 1 (minimal nationalism) to 10 (maximum Catalan/ Basque/ Galician or other non-Spanish nationalism). Again, party share has been considered and the index ranges from 0 to 10 for differences among parties on the identity scale. Table 2 shows the evolution of the two polarisation indices in Spain since the 2000 general elections ${ }^{3}$.

Table 2 Polarisation in Spanish elections, 2000-2019

\begin{tabular}{ccccc}
\hline Election & $\begin{array}{c}\text { Left-right } \\
\text { polarisation }\end{array}$ & Variation & $\begin{array}{c}\text { Territorial } \\
\text { polarisation }\end{array}$ & Variation \\
\hline 2000 & 3.75 & - & - & - \\
2004 & 4.15 & +0.4 & - & - \\
2008 & 4.24 & +0.09 & 3.75 & - \\
2011 & 4.39 & +0.15 & 4.75 & +1 \\
2015 & 4.73 & +0.34 & 5.03 & +0.28 \\
2016 & 5.04 & +0.31 & 5.04 & +0.01 \\
2019 & 5.10 & +0.06 & - & - \\
\hline
\end{tabular}

Source: Own elaboration with CIS data of pre- and post-electoral surveys for each general election.

\footnotetext{
${ }^{3}$ Elections have been considered depending on data available.
} 
As can be seen, polarisation has been increasing steadily in Spain. The widening polarisation on the left-right axis took place in the 2015-2016 period, when the two-party system changed to a four-party system. Polarisation along the territorial axis was especially relevant between 2008 and 2011, when the economic crisis and the judgement of the Constitutional Court concerning the reform of the Catalan Statute took place (Orriols \& Rodon 2016). Over the following years the increase was more moderate (unfortunately there are no available data for the 2019 election).

Recent evidence has pointed out how polarisation along the centre-periphery cleavage evolves together with the left-right scale (Galais and Serrano, 2019). The idea is that individuals that feel closer to the national state are pushed to the right as supporters of the status quo, and vice-versa: a tendency that seem to go beyond policy preferences. Therefore, it makes sense that both polarisation indices evolve together. In the case of Spain, the available data points to 2019 as the most polarised period in recent democratic times. This is understandable considering the two recent events that marked the 2019 electoral campaign. On the one hand, the territorial crisis. On the other hand, the rise of the radical right-wing party, VOX, made left-wing parties highlight the fact that it might well be the next kingmaker of a Spanish government. If just left-right polarisation is considered, it can be seen how it was a dynamic that was also significant during this period. Table 3 shows how citizens position each state-wide party on the left-right scale ${ }^{4}$.

Table 3 Left-right placement of parties in Spain

\begin{tabular}{lccccc}
\hline & UP & PSOE & Cs & PP & VOX \\
\hline January 2016 & 2.26 & 4.49 & 6.65 & 8.28 & - \\
April 2016 & 2.24 & 4.52 & 6.43 & 8.24 & - \\
May 2016 & 2.13 & 4.6 & 6.39 & 8.35 & - \\
October 2016 & 2.18 & 4.46 & 6.62 & 8.35 & - \\
January 2017 & 2.18 & 4.74 & 6.5 & 8.21 & - \\
April 2017 & 2.22 & 4.59 & 6.46 & 8.22 & - \\
June 2017 & 2.15 & 4.27 & 6.56 & 8.26 & - \\
October 2017 & 2.09 & 4.55 & 6.74 & 8.22 & - \\
January 2018 & 2.18 & 4.49 & 6.76 & 8.13 & - \\
April 2018 & 2.25 & 4.53 & 6.77 & 8.25 & - \\
June 2018 & 2.28 & 4.27 & 7.06 & 8.24 & - \\
September 2018 & 2.27 & 4.3 & 7.1 & 8.2 & - \\
October 2018 & 2 & 4.29 & 7.25 & 8.31 & - \\
November 2018 & 2.32 & 4.22 & 7.21 & 8.3 & - \\
December 2018 & 2.25 & 4.2 & 7 & 8.13 & - \\
January 2019 & 2.2 & 4.15 & 6.97 & 8.02 & 9.3 \\
February 2019 & 2.16 & 4.1 & 6.9 & 8.04 & 9.2 \\
April 2019 & 2.3 & 4.12 & 6.91 & 8.11 & 9.2 \\
\hline
\end{tabular}

$\mathrm{CIS}$ data from barometers. How voters place each party from 1 (extreme left) to 10 (extreme right)

Over the period, the centre-left PSOE and centre-right Ciudadanos moved in opposite directions. Despite the PSOE being considered more centrist during the territorial crisis - even after the return as PSOE leader of Pedro Sánchez, who supported invoking Article 155 in Catalonia - it was automatically perceived as more left-oriented when it arrived in government in June 2018. In the case of Ciudadanos, the opposite happened: starting from a more centrist platform, it gradually came to be perceived as more right wing. This movement only stopped with the appearance of VOX, that was perceived as

\footnotetext{
${ }^{4}$ Unfortunately, there are no data for the territorial axis in the CIS barometers.
} 
the farthest to the right in the system and moderated the other parties. This polarisation parallels an important volatility in the polls. Figure 1 shows the evolution of the parties in the polls.

Figure 1 Average of survey polls before the April 2019 general election

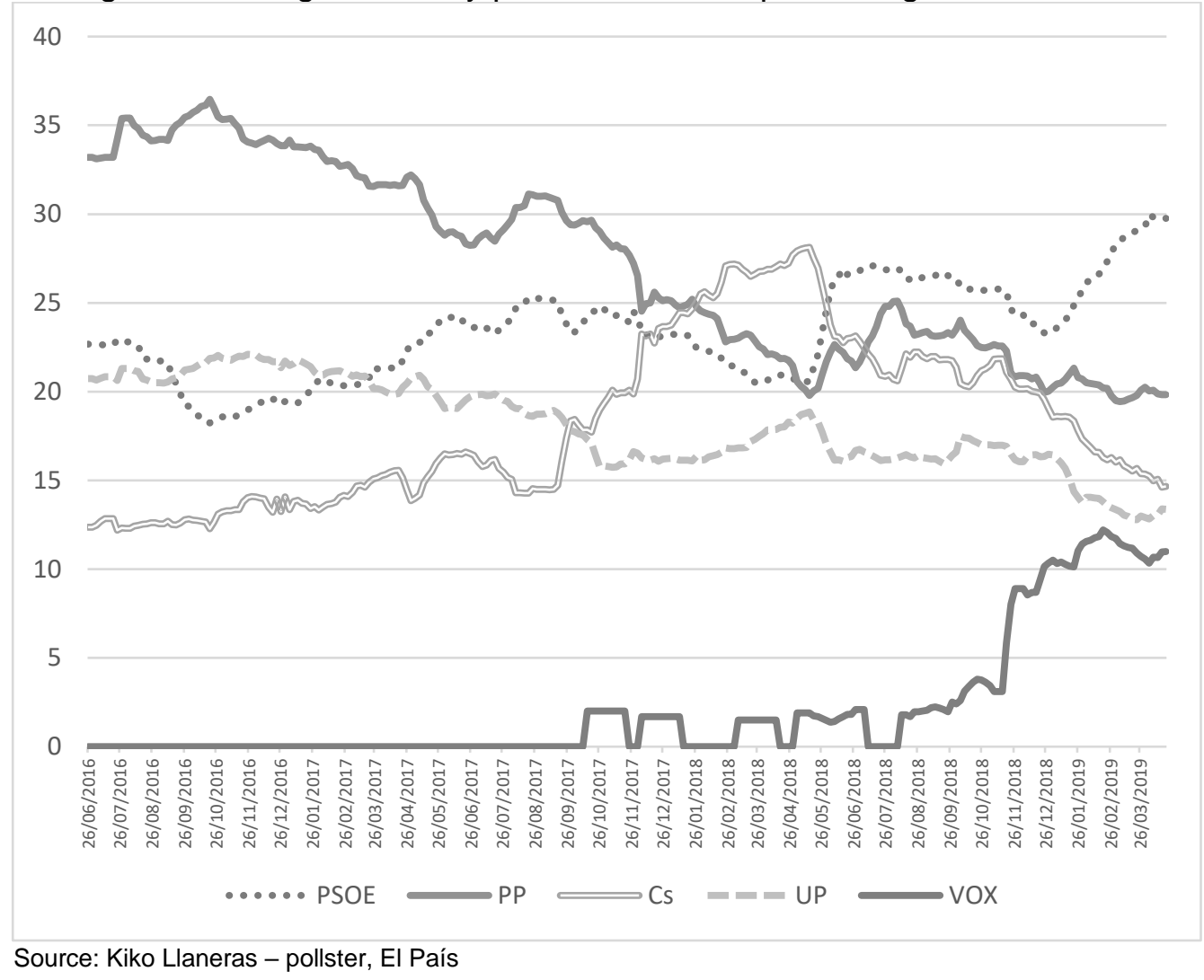

As can be seen, the Popular Party had been gradually losing support since Mariano Rajoy was made PM. The big change took place at the moment of the territorial crisis in Catalonia, when support for Ciudadanos rose dramatically, since the crisis was intimately linked with the very nature of this party. According to the CIS, in July 2017 no more than 2.6 per cent of those surveyed had indicated that the Catalan territorial crisis was the main problem of the country. In September, this rose 5 points and in October 2017 it reached its historical record, 24.6 per cent, a stark increase. Ciudadanos had been founded as a niche party against Catalan nationalism (Rodríguez-Teruel \& Barrio 2016) so when both the saliency of the territorial crisis and dissatisfaction with corruption were high, it was a good moment for Ciudadanos to gain support.

Nevertheless, the situation changed with the vote of no-confidence. The arrival of Pedro Sánchez in power created a honeymoon effect for the PSOE, putting the party in the lead in polls and diminishing Ciudadanos' position. The situation changed again with the appearance of VOX in Andalusia. It drove a slight recovery for the Socialists, caused a reduction in voting intention for other parties, while support for this new radical right-wing party rose to 12 per cent.

From 2014 onwards, the new party system in Spain had been characterised by its fragmentation and by the volatility of new parties that made it difficult to forge agreements and form governments (Simón 2017). This had implications for political competition, as can be seen when both within-bloc and between-bloc volatility are considered. Volatility is related to uncertainty, a component that tends to increase 
ideological differentiation, leading to political polarisation (Sartori 2005; Pardos-Prado \& Dinas 2010). Therefore, when it increases, the incentives of political parties to distinguish themselves from their political opponents also increase.

Table 4 shows this volatility, taking four moments in time into consideration: preand post-2017 constitutional crisis, post vote of no-confidence and pre-28 April general election. It displays the volatility within both the left-wing bloc (PSOE-UP) and the rightwing bloc (PP-CS-VOX). The 'Total Within' volatility refers to the sum of changes within blocs (left and right). The higher this value, the more the electoral changes across parties with similar ideologies. The 'Total Between' party volatility index refers to changes across parties across both ideological blocs. Finally, 'Total Volatility' is the sum of bloc and interbloc volatility ${ }^{5}$. The total vote share transfer between parties can be found in the online Appendix.

Table 4 Electoral volatility between and within left and right blocs

\begin{tabular}{l|cc|ccc}
\hline & Right bloc & Left bloc & Total Within & Total Between & Total Volatility \\
\hline October 2017 & 6.6 & 3.9 & 10.5 & 7.0 & 17.5 \\
April 2018 & 9.3 & 3.1 & 12.4 & 7.2 & 19.6 \\
October 2018 & 11.9 & 7.0 & 18.9 & 8.0 & 26.9 \\
April 2019 & 13.5 & 10.2 & 23.7 & 7.6 & 31.3 \\
\hline
\end{tabular}

Source: CIS. Barometers of October 2017, April 2017, October 2018 and pre-electoral survey of April 2018.

As can be seen, total within-bloc volatility grew during the whole period, while the volatility between blocs was relatively stable. When the territorial crisis was in the public eye and Ciudadanos gained ground, the difference between intra-bloc and between blocs volatility was not very high. In April 2018, Ciudadanos attracted 16.6 per cent of voters from the Popular Party, but also 7.5 per cent from the PSOE. In fact, about 40 per cent of the total vote change was due to transfers from left-wing to right-wing parties and vice versa. Nevertheless, volatility was higher on the right bloc than on the left bloc, simply because of the huge losses of the PP to Cs.

The situation changed after the arrival of Pedro Sánchez in government. In October 2018, intra-bloc volatility had risen dramatically. PP losses to Ciudadanos increased further, while the PSOE gained voters from Podemos. Volatility was higher on the right than on the left because of the considerable fragmentation of the right. This tendency accelerated even further prior to the general election. By April 2018 VOX was attracting voters from both the PP and from Ciudadanos, while the PSOE increased its gains from Podemos. The consequence was that, in relative terms, within bloc volatility rose again. In comparison with 2016, now the PSOE was the leading party on the left while the fragmentation on the right was higher, leading to three parties competing for the same space.

The consequence was the creation of a two-bloc logic with UP-PSOE on the left and Cs-PP-VOX on the right. This dynamic, that clarified the potential alliances that could be formed after elections, was conditioned by agent decisions. Despite the agreement reached in 2016 between PSOE and Ciudadanos to form a government (one that failed to pass the investiture vote) and the potential coalition power that the latter might have in a five-party system, it positioned itself only on the right. On 13 February Albert Rivera, leader of Ciudadanos, declared that his party would not come to any kind of agreement to govern with the PSOE (Santos, 2019). He declared that since the vote of noconfidence, Pedro Sánchez had excluded himself from the 'constitutional consensus'. This strategy was coherent with the gradual positioning of Ciudadanos as a more rightwing party by its voters (mostly ex-PP voters), the manifesto changes they presented,

\footnotetext{
${ }^{5}$ Volatility has been calculated using the Pedersen Index. This is one of the most common measures of aggregate stability and variation in party systems (Bartolini \& Mair 1990) and is quite straightforward to calculate: all the votes $(p)$ received by each party $(w)$ at election $\left(p w_{t}\right)$ are subtracted from all the votes received by each party at election $\mathrm{t}-1\left(\mathrm{pw}_{\mathrm{t}-1}\right)$.
} 
that moved it from a social democratic to a liberal party (Mateo 2017) and, in particular, the party's ambition to be the leading party in the right-wing bloc.

\section{Results of 28A General Election}

Turnout in April 2019 was over nine points higher than for the 2016 election, as can be seen in table 5 . This was not a surprise since in the previous election the turnout was below average - common in a repeat election - and since polarisation tends to correlate with higher electoral participation. The electoral results were quite similar to the opinion poll forecasts. The PSOE obtained 2.5 points and 2 million voters more than in 2016. With 123 seats, it had more than double the seats won by the party that came second. The PP obtained its worse result ever with 66 seats; it lost 71 MPs and more than 3.5 million voters (16.3 points). Ciudadanos came third and gained 2.8 points, only one point away from overtaking the PP's position. Unidos Podemos lost 29 seats (almost 7 points) and a third of its voters. VOX, the new party, emerged with 2,677,173 votes, 20.2 per cent and 24 seats.

At the same time, as a reaction to territorial polarisation, nationalist, regionalist and pro-independence parties gained ground. ERC became the most voted for party in Catalonia with 1,015,355 votes and 6 more seats than in 2016. Junts per Catalunya (the former PDeCAT) lost only one seat. With 394,627 votes, the PNV became the largest party in the Basque Country, a position that Podemos had held in the 2016 general election; the party also won one additional seat. Bildu doubled its seats from 2 to 4 , as did Coalición Canaria, from 1 to 2. Finally, Navarra Suma (a coalition made up of Union del Pueblo Navarro, Ciudadanos and PP) gained 2 seats and the regionalist parties from Valencia (Compromís) and Cantabria (PRC, Partido Regionalista de Cantabria) gained a seat each. Neither the PP, Cs nor VOX gained a single seat in the Basque Country. In Catalonia the PP gained only one seat (in Barcelona), underlining how right-wing statewide parties in Spain had lost ground in the traditionally pro-decentralisation territories.

Table 5 Main results in the 28A general election in Spain

\begin{tabular}{|c|c|c|c|c|}
\hline & \multicolumn{2}{|c|}{ Vote share Percentage } & \multicolumn{2}{|c|}{ Number of Seats } \\
\hline & 2019 & 2016 & 2019 & 2016 \\
\hline PSOE & 28.7 & 26.2 & 123 & 85 \\
\hline PP & 16.7 & 33 & 66 & 137 \\
\hline Ciudadanos & 15.9 & 13.1 & 57 & 32 \\
\hline$U^{1}$ & 14.3 & 21.2 & 42 & 71 \\
\hline VOX & 10.3 & & 24 & \\
\hline ERC & 3.86 & 2.6 & 15 & 9 \\
\hline JxCat & 1.9 & 2 & 7 & 8 \\
\hline PNV & 1.5 & 1.2 & 6 & 5 \\
\hline Bildu & 0.9 & 0.8 & 4 & 2 \\
\hline CC & 0.5 & 0.3 & 2 & 1 \\
\hline Compromís & 0.6 & & 1 & \\
\hline Navarra $+^{2}$ & 0.4 & & 2 & \\
\hline PRC & 0.2 & & 1 & \\
\hline Turnout & 75.7 & 66.4 & & \\
\hline
\end{tabular}


Note 1: The shares have been considered according to the sum of Unidos Podemos (11 per cent) ECPGuanyem el Canvi (2.3 per cent) and Podemos-EU-Mareas en Común-Equo (0.9 per cent).

Note 2: Navarra Suma is a coalition made up of the regional conservative party UPN, PP and Ciudadanos in Navarra.

The electoral system also played a role. The small district size and the fact that a third of the districts elect fewer than five seats each tend to benefit the winning and second parties, creating important disproportionality (Penadés \& Santiuste 2013). The PSOE won in 39 of the 50 provinces and, as result, was over-represented in the Congress by 6.4 points, followed by the PP with 2.1 points. Ciudadanos received a similar share of seats to the votes they had won while UP was under-represented by about 2 points and VOX, the smallest nationwide party, by 3.4 points. Thus, the PSOE and, consequently, the left bloc, was more efficient in translating votes into seats. Table 6 shows the vote share transfers compared with the 2016 general election considering post-electoral data from the Centro de Investigaciones Sociologicas.

Table 6 Percentage of vote transfers in general elections (2019-2016)

\begin{tabular}{lcccc}
\hline \multicolumn{4}{c}{ Voted for in 2016 } \\
\hline Voted for in & PP & PSOE & UP & Cs \\
\hline PP & 50.1 & 0.8 & 0 & 3.7 \\
PSOE & 6.5 & 81.8 & 19.3 & 9.7 \\
UP & 1.6 & 3.2 & 70.7 & 3 \\
Cs & 14.9 & 4.1 & 0.9 & 65.7 \\
VOX & 15.1 & 0.9 & 0 & 8.8 \\
Others & 11.8 & 9.2 & 9.1 & 9.1 \\
Abstention/blank & 5.7 & 3.4 & 2.4 & 3.2 \\
Total & 100 & 100 & 100 & 100 \\
Source: ClS post-electoral survey & & &
\end{tabular}

The results were consistent with intra-bloc volatility. The PP retained the lowest number of voters and lost about 15 per cent in favour of Ciudadanos and VOX respectively. Conversely, the PSOE retained more than 81 per cent of its 2016 voters and won 19.3 per cent of Podemos' 2016 voters too. Meanwhile, Ciudadanos lost 9.7 per cent of its voters to the PSOE - almost double the voters who switched the other way - while 8.8 per cent of Ciudadanos' 2016 voters voted for VOX in 2019. The results were closely aligned with the expectations built up prior to the general election. Polarisation benefitted the PSOE as the main party on the left - and the governing party - while voters on the right were fragmented.

\section{Results of the European, regional and local elections}

After the general election, all the parties decided to postpone negotiations to form a government until the 26M European, regional and local elections. In general, the leftwing parties followed a similar strategy to the one they had followed in the previous contest. The polls indicated that the PSOE had benefitted from its success in the general elections and would be the most voted for party in all three elections (Pinheiro \& Barandela, 2019). Nevertheless, it was not clear that the PSOE had the capacity to forge a majority in all regional assemblies to compensate for the losses that would be suffered by Podemos, its parliamentary partner in minority governments.

In contrast, the right-wing parties adapted their strategies. In addition to Ciudadanos wavering about their veto against making agreements with the PSOE at the regional level, the greatest change was the Popular Party's campaign. As a reaction to its poor results in the general election, Pablo Casado moderated the PP's discourse to 
make it more centrist (Casqueiro 2019). His previous campaign had been very focused on highlighting differences with the PSOE and imitating VOX on cultural and territorial issues. In the regional and local campaign, the Popular Party opened up to agreements with Sánchez about immigration or the European Unión, shifting to a more moderate platform. In any case, everyone's attention was placed on the Madrid region. If the PP was not able to maintain this stronghold, the PP leadership would be at risk.

According to the schedule fixed by the Electoral Law, three kinds of elections are held on the same day. Firstly, just like in the rest of European Union, elections to the European Parliament were to be held. Spain elects 54 MEPs in a nationwide district with no electoral threshold, using the d'Hondt allocation method and closed lists. Second, local elections were to take place on the same day in the 8,114 Spanish municipalities. Citizens elect a number of town councillors, depending on the town's population, in a proportional system with a closed list and the d'Hondt system. These councillors elect the City Mayor with an absolute majority or, failing that, the frontrunner of the winning party is elected automatically. Finally, there were to be elections in the 'slow track' regions $^{6} ; 12$ of the 17 Spanish Autonomous Communities: Asturias, Cantabria, Navarra, La Rioja, Aragón, Castilla y León, Region of Madrid, Castilla-La Mancha, Extremadura, the Balearic Islands, Region of Murcia and the Canary Islands. The exception was the Comunitat Valenciana, which had held its elections the same day as the general election. According to its Statute of Autonomy, the president can call for elections when he or she considers them opportune. In this way, in most places, the three elections were conflated into a single campaign.

Two things should be underlined about the specificity of regional and local elections. First, fragmentation tends to be higher at regional and local levels. As a consequence, minority or coalition governments are not rare, despite both Podemos and Ciudadanos deciding not to participate in any cabinet after the 2015 elections (Ramos \& Simón 2015). In the 2019 election, both parties indicated that they would form coalition governments. Second, it was difficult for Podemos, Ciudadanos or VOX to overtake the PSOE or the PP in local or regional elections. The reason is that traditional parties have a wider territorial structure and can present candidacies everywhere and, therefore, will always obtain better results. Because of the complexity and importance of the elections, the media gave plenty of coverage to the region of Madrid and the municipalities of Madrid and Barcelona. Table 7 shows the results of the European elections.

Table 7 Results of the 2019 and 2014 European elections in Spain

\begin{tabular}{|c|c|c|c|c|}
\hline & \multicolumn{2}{|c|}{ Vote share percentage } & \multicolumn{2}{|c|}{ Number of Seats } \\
\hline & 2019 & 2014 & 2019 & 2014 \\
\hline PSOE & 32.8 & 23 & 20 & 14 \\
\hline PP & 20.1 & 26.1 & 12 & 16 \\
\hline Ciudadanos & 12.1 & 3.1 & 7 & 2 \\
\hline Podemos $^{1}$ & 10.7 & 7.9 & 6 & 5 \\
\hline IU & - & 10 & - & 6 \\
\hline UPyD & - & 6.5 & - & 4 \\
\hline VOX & 6.2 & 1.5 & 3 & 0 \\
\hline $\mathrm{ERC}^{2}$ & 5.5 & 4 & 3 & 2 \\
\hline $\mathrm{JxCat}^{3}$ & 4.54 & 5.4 & 2 & 3 \\
\hline PNV & 2.82 & - & 1 & - \\
\hline Bildu & - & 2 & - & - \\
\hline Compromís & 1.32 & 1.9 & 0 & 1 \\
\hline
\end{tabular}

\footnotetext{
${ }^{6}$ This distinction refers to those Autonomous Communities that were not created based on the autonomies in the Second Republic (Catalonia, the Basque Country and Galicia) or by the requisite clause in the Constitution to do so (Andalusia).
} 
Source: Own compilation from the Ministry of the Interior. Note 1: In 2019 Unidas Podemos, the coalition of Podemos and United Left, competed together. The variation takes the sum of both parties in 2014 into account. Note: ERC competed in coalition with Bildu in 2019. The variation takes the sum of both parties in 2014 into account. Note 3: JxCat competed in a coalition with the PNV in 2014, but not in 2019.

Turnout rose notably, by more than 20 points, because the effect of having a simultaneous local election and regional contest cancelled out the low turnout associated with second order elections (Cordero \& Montero 2015). The PSOE was the most voted for party, with 7,369,789 votes and 20 seats, increasing its 2014 results by almost 10 points. The PP lost 6 points and 4 seats, but Ciudadanos was far from its tie with the PP on 28A: they obtained 2.7 million votes in comparison with 4,316,600 votes in the general election - but gained 5 seats. Podemos, now in coalition with United Left, had fewer votes than the sum of both parties in 2014, and added only one new seat. VOX, which had not won any seats in the 2014 European elections, now gained 3 seats and 1,393,648 votes, about one million votes fewer than its results one month earlier. Thus, there are good reasons for assuming that European election behaviour was considerably aligned with regional and local elections, where both the PSOE and the PP have a relative advantage compared to other parties.

Table 8 shows the results of the regional elections. There are some patterns common to all the Spanish regions. First, apart from in Navarra and Cantabria, the PSOE was the party with the most votes in all regions. Second, Ciudadanos and VOX increased their representation while the vote share of the PP went down, but less so than in the general elections. Ciudadanos replaced Podemos as the third party in the majority of regions and VOX obtained about half of what they had achieved in the general election but failed to gain any seats in 5 of the autonomous communities. Finally, Unidas Podemos (now in coalition with United Left) sharply lost support everywhere. 
Table 8 Results of the 2019 regional elections in Spain: Voting percentages (and seats) compared to the previous election

\begin{tabular}{|c|c|c|c|c|c|c|c|}
\hline & PSOE & PP & Cs & Podemos & IU & VOX & Others \\
\hline \multirow[t]{2}{*}{ Asturias $^{a}$} & $35.2(20)$ & $17.5(10)$ & $13.9(5)$ & $11(4)$ & $6.6(2)$ & $6.4(2)$ & $6.5(2)$ \\
\hline & $+21.2(6)$ & $-4(-1)$ & $+6.8(2)$ & $-8(-5)$ & $-5 .(-3)$ & & $-1.6(-1)$ \\
\hline \multirow[t]{2}{*}{ Aragón ${ }^{b}$} & $30.8(24)$ & $20.8(16)$ & $16.7(12)$ & $8(5)$ & $3.3(1)$ & $6(3)$ & $11.2(3+3)$ \\
\hline & $+9.4(6)$ & $-6.7(-5)$ & $+7.2(7)$ & $-12.5(-9)$ & -1.1 & & $+0.3(-3+1)$ \\
\hline \multirow[t]{2}{*}{ Cantabria $^{c}$} & $17.6(7)$ & $24(9)$ & $8(3)$ & $3.1(0)$ & & $5(2)$ & $37.7(14)$ \\
\hline & $+3.6(2)$ & $-8.6(-4)$ & $+2.1(1)$ & $-8.2(-3)$ & & & $+5.7(2)$ \\
\hline \multirow[t]{2}{*}{ Castilla y León ${ }^{d}$} & $34.8(35)$ & $31.5(29)$ & $14.9(12)$ & $5(2)$ & & $5.5(1)$ & $2.69(1+1)$ \\
\hline & $+8.9(10)$ & $-6.2(-13)$ & $+4.9(7)$ & $-11.1(-7)$ & & & $+1.56(+1)$ \\
\hline \multirow[t]{2}{*}{ Castilla-La Mancha } & $44.1(19)$ & $28.5(10)$ & $11.3(4)$ & $6.9(0)$ & & $7(0)$ & \\
\hline & $+8(4)$ & $-9(-3)$ & $2.7(4)$ & $-5.9(2)$ & & & \\
\hline \multirow[t]{2}{*}{ Comunitat Valenciana $^{\mathrm{e}}$} & $23.8(27)$ & $18.8(19)$ & $17.4(18)$ & $7.9(8)$ & & $10.4(10)$ & $16.4(17)$ \\
\hline & $+3.5(4)$ & $7.4(-12)$ & $5.1(5)$ & $-4.3(-5)$ & & & $-2.3(-2)$ \\
\hline \multirow[t]{2}{*}{ Extremadura } & $46.7(34)$ & $27.4(20)$ & $11.1(7)$ & $7.1(4)$ & & $4.7(0)$ & \\
\hline & $+5.2(4)$ & $-9.6(-8)$ & $7.8(6)$ & $-5.1(-2)$ & & & \\
\hline \multirow[t]{2}{*}{ Navarra $^{\dagger}$} & $20.6(11)$ & $36.5(20)$ & & $4.7(2)$ & $3(1)$ & $1.3(0)$ & $21.8(9+7)$ \\
\hline & $+7.3(4)$ & $+2.7(+3)$ & & $-3.1(-5)$ & $-0.6(-1)$ & & $+1.6(0-1)$ \\
\hline \multirow[t]{2}{*}{ La Rioja } & $38.7(15)$ & $33.1(12)$ & $11.5(4)$ & $6.6(2)$ & & $3.8(0)$ & \\
\hline & $+12(+5)$ & $-5.3(-3)$ & $-1(=)$ & $-8.6(-2)$ & & & \\
\hline \multirow[t]{2}{*}{ Balearic Islands ${ }^{g}$} & $27.2(19)$ & $22.2(16)$ & $9.8(5)$ & $9.7(6)$ & & $8.1(3)$ & $18.3(4+3+2+1)$ \\
\hline & $+8.3(+5)$ & $-6.3(-4)$ & $+3.9(+3)$ & $-4.9(4)$ & & & $-5.4(-2+0+1+0)$ \\
\hline \multirow[t]{2}{*}{ Canary Islands ${ }^{h}$} & $28.8(22)$ & $15.1(19)$ & $7.3(2)$ & $8.7(3)$ & $1(0)$ & $2.4(0)$ & $31.5(17+4+3)$ \\
\hline & $+9(7)$ & $-3.4(-7)$ & $1.4(+2)$ & $-5.8(-4)$ & $-1.2(0)$ & & $+2.5(-1-1+0)$ \\
\hline \multirow[t]{2}{*}{ Region of Madridi } & $27.3(37)$ & $22.2(30)$ & $19.4(26)$ & $5.5(7)$ & & $8.8(12)$ & $14.6(20)$ \\
\hline & $+1.9(=)$ & $-10.9(-18)$ & $+7.3(9)$ & $-17.1(-20)$ & & & \\
\hline \multirow[t]{2}{*}{ Region of Murcia } & $32.4(17)$ & $32.3(16)$ & $12(6)$ & $5.5(2)$ & & $9.4(4)$ & \\
\hline & $+8.5(+5)$ & $-5(-6)$ & $-0.5(+2)$ & $-12.4(-4)$ & & & \\
\hline
\end{tabular}


Source: Own compilation from the Ministry of the Interior. Regional parties included in the category 'Others' are: a: Foro Asturias (conservative); b: PAR (conservative) and Cha (leftists); c: PRC (centrist); d: UPL (regionalist from León) and XAV (For Avila); e: Compromís (regionalist left); f: GeroBai (PNV- centrist) and Bildu (leftist); g: MES (leftist), PI (centrist), MeXM (Regionalist from

island); i: Mas Madrid (leftist, former group of Podemos). 
As can be seen in table 9, the regional results had implications in terms of government formation. The PSOE had an absolute majority in Extremadura and Castilla-La Mancha, something that was unexpected in the new multiparty system. In addition, the Socialists were also able to retain all the regions they already governed (Asturias, Aragón and the Balearic Islands) and in Comunitat Valenciana, that had held its election one month before, the PSOE once again formed a coalition with the regionalist party Compromís and with Unidas Podemos. The PSOE also gained through coalitions the governments of Navarra (from the Geroa Bai-Bildu coalition), the Canary Islands (from Coalición Canaria) and La Rioja (from the PP). The novelty was that in all cases the regions changed their government structure: from single minority PSOE governments to coalition governments with regional parties and/or Podemos.

Ciudadanos was the kingmaker party in Castilla y León, Murcia and, with third party alliances, in the Madrid Region. They had the option of making pacts with either the PSOE or the PP. Nevertheless, they followed the same alliance policies as in the general election: their regional branches favoured agreements with the PP, forming coalition governments without direct negotiations with either Podemos or VOX (Ramirez, 2019). Consequently, in those three regions Ciudadanos formed a minority coalition government with the PP. Like in Andalusia, VOX did not have representation in the cabinet and, despite postponing negotiations, eventually supported those governments. It was considered that retaining those regions allowed Pablo Casado, leader of the PP, to affirm his candidacy in new elections (Junquera 2019).

Finally, in the local elections, the PSOE went from 17 to 20 provincial capitals. The Socialists had an absolute majority in Soria and Huelva, and through alliances they governed Valladolid, Seville, Toledo, Cuenca, Guadalajara, Logroño, Jaén and Lugo. The PP went from 21 to 13 (they lost traditional strongholds such as Ávila, Burgos and Palencia). However, the PP in a coalition with Cs and VOX won Madrid and Zaragoza from Podemos, and also, with the same formula, won Córdoba from the PSOE. Thus, despite losing several cities, the PP gained the capital and the fifth and the thirteenth most populated cities. It was read as a clear victory for the conservatives. Ciudadanos, in alliances with the PP, gained Palencia and Granada and, in an alliance with the PSOE, took Melilla and with a two-year share each, Ciudad Real and Albacete.

Podemos platforms, with respect to their victories in 2015, only held onto Cádiz. Significantly, City Mayor Ada Colau held onto Barcelona. Despite ERC being the frontrunner in the election, Manuel Valls, the independent candidate that headed the Ciudadanos list, decided to support the Podemos incumbent in order to prevent the proindependence party from ruling the city. As a result, he was struck off the Ciudadanos list. ERC gained Lleida and Tarragona, expanding its territorial power significantly, while the PNV retained all three Basque Country capitals and Compromís held onto Valencia. 
Table 9 Regional governments in Spain after the 2015 and 2019 elections

\begin{tabular}{|c|c|c|c|c|c|c|}
\hline & \multicolumn{3}{|c|}{2015} & \multicolumn{3}{|c|}{2019} \\
\hline & $\begin{array}{c}\text { Parties in } \\
\text { government }\end{array}$ & $\begin{array}{c}\text { Type of } \\
\text { government }\end{array}$ & $\begin{array}{c}\text { Parliamentary } \\
\text { Support }\end{array}$ & $\begin{array}{c}\text { Parties in } \\
\text { government }\end{array}$ & $\begin{array}{c}\text { Type of } \\
\text { government }\end{array}$ & $\begin{array}{l}\text { Parliamentary } \\
\text { Support }\end{array}$ \\
\hline Asturias & PSOE & Minority & & PSOE & Minority & IU \\
\hline Aragón & PSOE & Minority & Podemos, CHA, IU & $\begin{array}{l}\text { PSOE, PAR, } \\
\text { UP, CHA }\end{array}$ & $\begin{array}{c}\text { Minimal winning } \\
\text { coalition }\end{array}$ & \\
\hline Cantabria & PRC, PSOE & $\begin{array}{l}\text { Minority } \\
\text { coalition }\end{array}$ & Podemos & PRC, PSOE & $\begin{array}{c}\text { Minimal winning } \\
\text { coalition }\end{array}$ & \\
\hline Castilla y León & PP & Minority & Cs & PP, Cs & $\begin{array}{c}\text { Minimal winning } \\
\text { coalition }\end{array}$ & \\
\hline Castilla-La Mancha & PSOE, UPa & $\begin{array}{l}\text { nimal winning } \\
\text { coalition }\end{array}$ & & PSOE & Majority & \\
\hline Comunitat Valenciana & PSOE, Comp. & $\begin{array}{l}\text { Minority } \\
\text { coalition }\end{array}$ & Podemos & $\begin{array}{l}\text { PSOE, Comp., } \\
\text { UP }\end{array}$ & $\begin{array}{c}\text { Minimal winning } \\
\text { coalition }\end{array}$ & \\
\hline Extremadura & PSOE & Minority & Podemos & PSOE & Majority & \\
\hline Navarra & GBai, Bildu, IU & Minority & Podemos & $\begin{array}{l}\text { PSOE, GBai, } \\
\text { UP }\end{array}$ & $\begin{array}{l}\text { Minority } \\
\text { coalition }\end{array}$ & Bildu \\
\hline La Rioja & PP & Minority & Cs & $\begin{array}{c}\text { PSOE, } \\
\text { Podemos }\end{array}$ & $\begin{array}{l}\text { Minority } \\
\text { coalition }\end{array}$ & IU \\
\hline Balearic Islands & PSOE, MES & $\begin{array}{l}\text { Minority } \\
\text { coalition }\end{array}$ & Podemos & $\begin{array}{l}\text { PSOE, UP, } \\
\text { MES }\end{array}$ & $\begin{array}{c}\text { Minimal winning } \\
\text { coalition }\end{array}$ & \\
\hline Canary Islands & $\mathrm{CC}^{\mathrm{b}}$ & Minority & & $\begin{array}{c}\text { PSOE, NC, AG, } \\
\text { UP }\end{array}$ & $\begin{array}{c}\text { Minimal winning } \\
\text { coalition }\end{array}$ & \\
\hline Region of Madrid & PP & Minority & Cs & $\mathrm{PP}, \mathrm{Cs}$ & $\begin{array}{l}\text { Minority } \\
\text { coalition }\end{array}$ & VOX \\
\hline Region of Murcia & PP & Minority & Cs & $\mathrm{PP}, \mathrm{Cs}$ & $\begin{array}{l}\text { Minority } \\
\text { coalition }\end{array}$ & VOX \\
\hline
\end{tabular}

Source: Own compilation. a: Minority government of the PSOE was formed in 2015 with the support of Podemos, but both parties entered in a coalition in July 2017; b: Coalition government between CC and PSOE was formed in 2015 but it was broken in December 2016 and Coalición Canaria ruled in with a minority government. 


\section{The political implications of a polarised Spain}

Different conclusions can be drawn regarding the results of the general, European, regional, and local elections. First, in the general elections, fragmentation rose to its highest level ever since the restoration of democracy in 1977. As can be seen in Fig. 2, in 2019, the effective number of electoral parties (ENEP) ${ }^{7}$ increased to 6 and the parliamentary parties (ENPP) to 5 . The sum of the votes of the PSOE and the PP was only 46 per cent, the lowest value since the restoration of democracy. This value was higher in the European elections, where they obtained 52 per cent of votes, and in the regional elections, where the traditional parties obtained 55 per cent thanks to their territorial structure. Thus, fragmentation increased sharply again during the electoral cycle but more at the national than at the local and regional level.

Figure 2 Party system fractionalisation in Spain

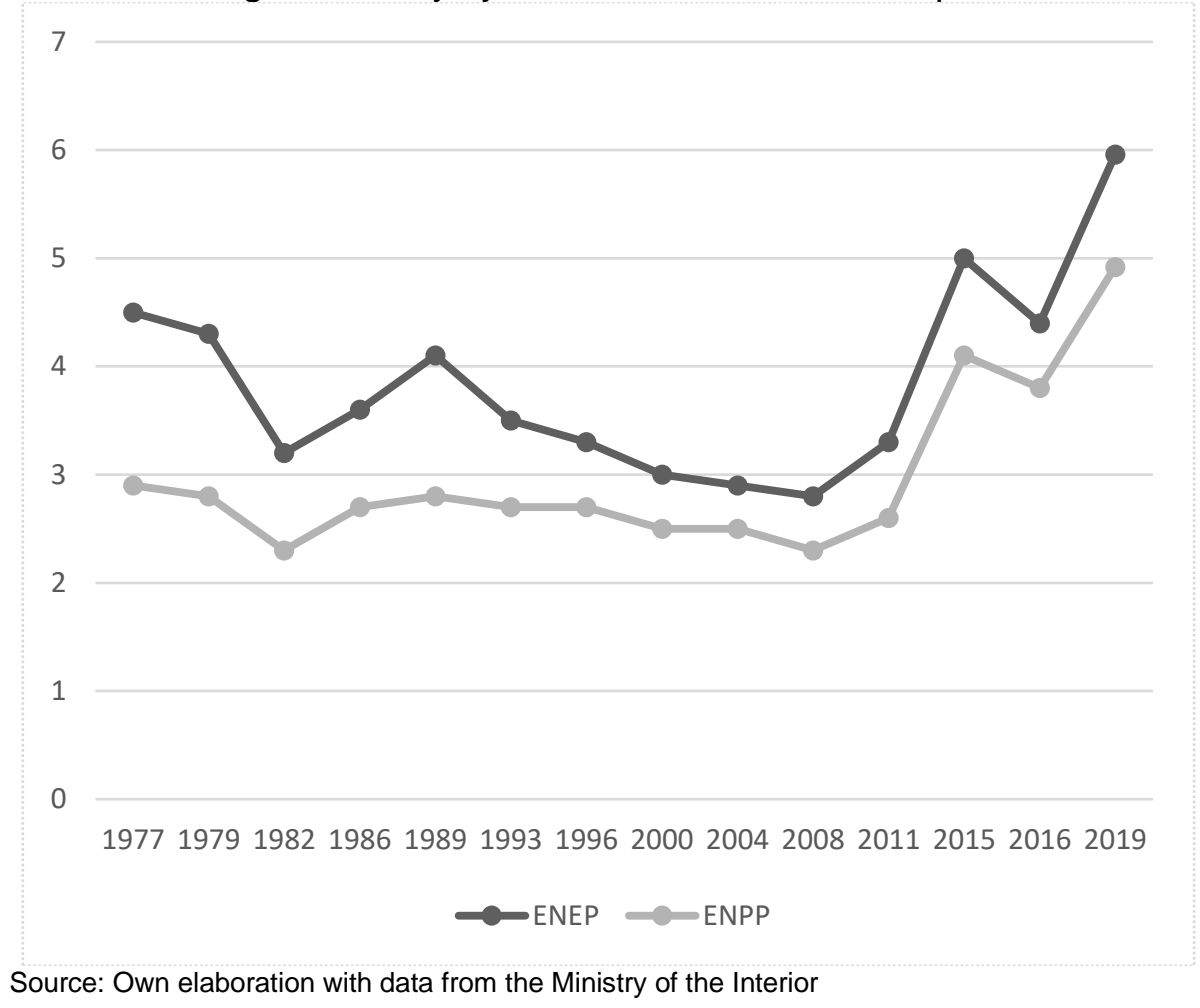

There were important differences in the levels of support for each party across the competitive arena. The two traditional parties, the PSOE and the PP, gained approximately the same votes in general and European elections, about 7.3 and 5.3 million voters each. However, in local elections the PSOE lost about 1 million voters while the PP remained practically the same across elections. Podemos retained a similar number of votes in the general and the European elections, despite losing about a third in the regional and the local ones. The situation was very different for Ciudadanos, that went from 4.1 million voters in the general election to losing two million voters in

\footnotetext{
${ }^{7}$ The effective number of parties is calculated as follows: $E N P=\frac{1}{\sum_{i=1}^{n} p_{i}^{2}}$

where $p$ is the proportion of votes obtained by party $i$ in the election. The Effective Number of Parliamentary Parties replaces $p$ with the share of seats obtained by each party. (Laakso \& Taagepera 1979).
} 
European and three million voters in the local elections. Finally, VOX went from 2.3 million voters in the general election to half of that in the European elections and only about 500,000 votes in the local contest. Again, the new parties lacked the structure to compete efficiently at the regional and at the local level.

A second associated element has proved that the cycle of institutionalisation of the party system, understood as the extent to which competitive political regimes develop stable patterns of interparty competition, has not yet finished (Mainwaring \& Zoco, 2007). As shown in figure 3, electoral volatility was also high in the 2019 general election. Despite the volatility regarding new parties being related with the appearance of VOX (10.2 per cent votes) the vote change between PSOE, PP, Cs and UP was also significant. The combination of a multiparty system with a volatile context necessarily affects party strategies. When there are three parties (Ciudadanos, Podemos and VOX) which are under stress and lack a well-defined loyal voter base, and when the PP also faces new competition in its political space, there is increased incentive for the different organisations to stress their differences. That is, when it is unclear that party supply has reached an equilibrium, and when uncertainty is high, the parties have incentives for increased polarisation.

Figure 3 Electoral volatility to traditional and new parties in Spanish elections

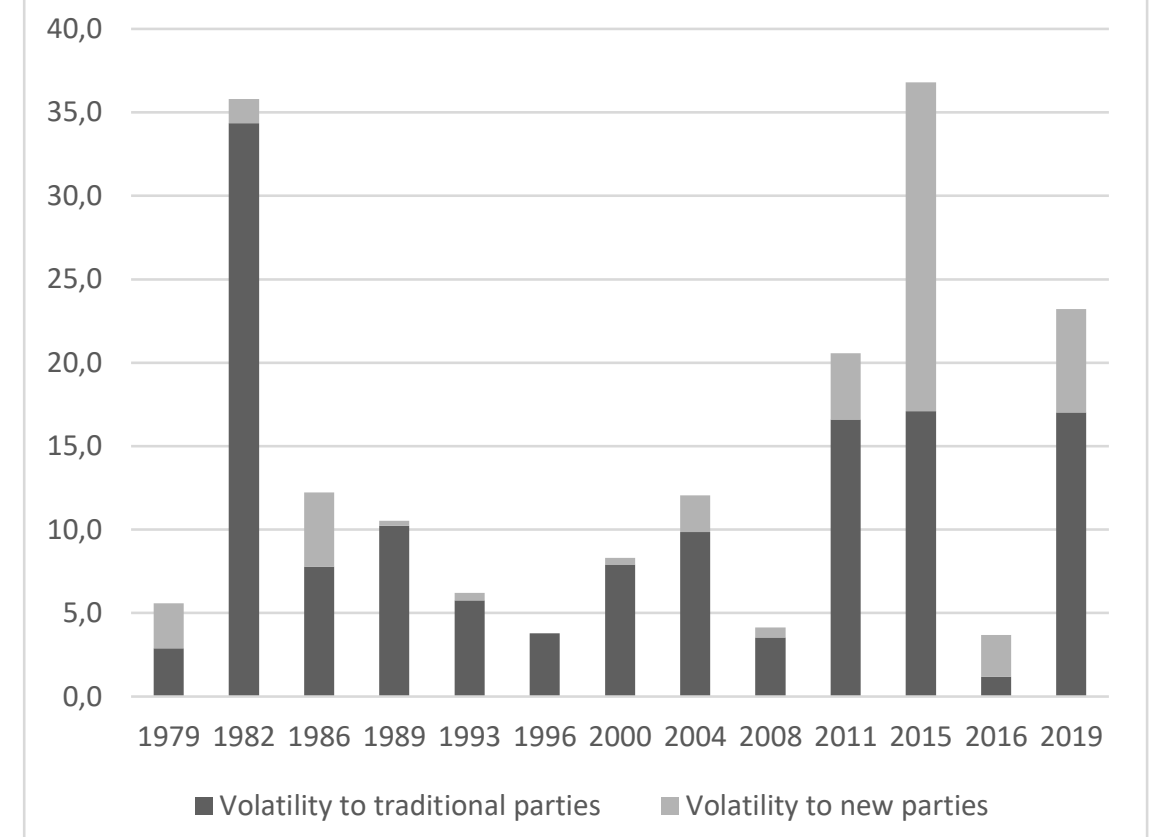

Source: Own elaboration with data from the Ministry of Interior. The figure distinguishes between volatility to new parties (that did not have seats in the previous parliament) and volatility to traditional parties.

The third implication, then, is that polarisation will not disappear in the short term in Spain. Uncertainty created by electoral volatility tends to be linked to ideological differentiation (Sartori, 2005; Pardos-Prado \& Dinas, 2010). Moreover, agency decisions play a role in stressing the extent to which left-right differences are associated with centre-periphery cleavage (Dinas, 2012). In this sense, two components might contribute.

On the one hand, the constitutional crisis suffered in Catalonia in 2017 deeply affected the Catalan parties. The pro-independence parties are now engaged in an internal fight related to ethnic outbidding (Barrio \& Rodríguez-Teruel 2017) that makes any potential agreement in the short term difficult, while internal leadership in the proindependence camp, ERC or JxC, cannot be clarified without a new Catalan election. Moreover, the trial against the Catalan leaders in 2018, with its own procedural logic, has also increased tension and made the position of the pro-independence agents far more rigid. Thus, it is not only the national, but also the regional arenas (Catalonia, in this case) 
that need to be considered in the case of Spain. On the other hand, the right-wing Spanish parties are also competing to show how they fiercely oppose the proindependence movement and its demands; their reactions range from calling for the suppression of Autonomous Communities (VOX) to a permanent application of article 155 (PP and Cs), with neither option being contemplated in the constitution. Thus, competition also shows how both the left-right and territorial dimensions converge.

This polarisation also has implications for party alliances. Before 2014, when neither the PSOE nor the PP had absolute majorities, they reached agreements with the moderate Catalan and Basque nationalists, $\mathrm{CiU}$ and/ or the PNV (Falcó-Gimeno \& Verge 2013). This logic is reproduced in the new multiparty system because, if the PSOE and UP cannot obtain an absolute majority, they will always require the support or abstention of regionalist/pro-independence parties. Nevertheless, the situation is more complex when one considers that the right-wing bloc rejects any kind of cooperation with Catalan and Basque parties. Nowadays any PP-Cs agreement to govern will require the support of the radical right-wing party VOX, making it impossible to garner the support of moderate Catalan or Basque nationalist parties. Thus, because of this new situation with the regional parties, right wing parties will be required to reach a near absolute majority by themselves to rule, while the left does not face this requisite.

This is also related to how the two-bloc logic has overruled the idea of 'centrist' coalitions. In the 2019 general elections, the minimum winning coalition would have been an agreement between PSOE and Cs such as the one they had already signed in 2016 (Simón 2016). This coalition would have obtained 180 seats. Nevertheless, the logic og polarisation - especially after Sánchez's 2018 vote of no confidence which brought down the Rajoy government - led Ciudadanos' leaders to emphasise its right-wing orientation, making this agreement impossible. This strategic decision in the case of Ciudadanos led to the resignation of important members of its central bureau (Sanz 2019). It is obvious that Ciudadanos' decision not to change its position about negotiations after the $28 \mathrm{~A}$ election has the virtue of allowing clear coalition signalling for voters, but it also implies that any government formation process will require more agents, thus increasing its complexity.

\section{Conclusions}

The 2019 general, European, regional and local elections in Spain took place in a context of fragmentation, electoral volatility and, especially, polarisation. Despite this last dynamic increasing steadily over the last decade, it was closely linked to the Catalan constitutional crisis in October 2017 and the arrival of Pedro Sánchez's government through a vote of no-confidence in May 2018. The implication of this polarisation was the emergence of the new radical right-wing party, VOX, and also the creation of a two-bloc system in which left-right differences also interacted with the approaches to the Catalan conflict. This paper has shown the evolution of the Spanish context since the 2016 election and how agent decisions led to a twofold conflict in subsequent elections held in 2019. In the case under discussion, while the PSOE won votes from UP, the PP lost in favour of two different parties, Ciudadanos and VOX, with fragmentation being higher on the right than on the left.

The paper also identifies how fractionalisation and electoral volatility were intimately linked to an increase in ideological differentiation both in the territorial and the left-right dimensions. In contrast with other countries, it is not the post material cleavage that is coexisting with the economic axis, but the identity cleavage, which presents a nonorthogonal relationship with left-right positions. There are historical roots that link peripheral nationalism with the left in Spain and connect the right with more centralist positions. However, the relationship is not only based on historical reasons, but also on agency decisions taken during the recent period prior to the 2019 electoral period.

The paper also explores the results of the elections. The PSOE was the party with the most votes and the only one that could build a majority in parliament. Polarisation 
prevented Pedro Sánchez from seeking support from Ciudadanos, so his only option was to forge a government with UP, which had lost many votes and seats, bolstered by the implicit support of the Catalan pro-independence parties. The PP suffered its worst results in recent history and was almost overtaken by Ciudadanos, while VOX won its first seats in Congress. However, the situation was different in the European, regional and local elections, where both the PP and the PSOE had more structure. The result was again advantageous for the Socialists, who gained three additional regions and cities, while the PP kept three of the four it had at stake. Unidas Podemos and Cs entered into coalitions with the major parties - the PSOE and the PP respectively - but always as junior partners. In fact, as with VOX, they obtained far worse results than in the general election one month earlier.

Finally, it is highly unlikely that there will be less polarisation in Spain in the short term since the new multiparty system, which was born in 2014, is not a stable institutionalised equilibrium. There is still a possibility that new parties will emerge, while the newest parties such as UP or VOX face existential threats. This means that all the actors have incentives to distinguish themselves from rival parties within and across ideological blocs.

\section{References}

Aduriz, I. (2019) 'Casado abre por primera vez la puerta a que Vox entre en su Gobierno si las derechas suman el 28A', El Diario, 26 April, available online at: https://www.eldiario.es/politica/Casado-primera-Vox-Gobiernoderechas 0 892760909.html

Barrio, A., \& Rodríguez-Teruel, J. (2017). 'Reducing the gap between leaders and voters? Elite polarisation, outbidding competition, and the rise of secessionism in Catalonia', Ethnic and Racial Studies, vol. 40, no.10, pp. 1776-1794.

Bartolini, S., \& Mair, P. (1990). 'Policy competition, spatial distance and electoral instability', West European Politics, vol.13, no.4, pp. 1-16.

Carpio, J.A. (2018) 'La Audiencia Nacional condena al PP por lucrarse de la trama Gürtel y acredita la caja B', RTVE, 24 May, available online at: http://www.rtve.es/noticias/20180524/caso-gurtel-audiencia-nacional-condena-pplucrarse-trama-gurtel-acredita-caja/1738968.shtml

Carranco, R. (2017) 'La justicia desmonta la organización del referéndum ilegal de Cataluña', El País, 21 September, available online at: https://elpais.com/ccaa/2017/09/20/catalunya/1505885372 273143.html 
Cruz, M. (2016) 'Mariano Rajoy, investido gracias a la abstención de todos los diputados del PSOE excepto 15', EI Mundo, 29 October, available online at:

https://www.elmundo.es/espana/2016/10/29/5814b9cb46163fce668b4581.html

Casqueiro, J. (2019) ‘Casado suaviza su estrategia y ofrecerá pactos a Sánchez’, El País, May, available online at:

https://elpais.com/politica/2019/05/02/actualidad/1556819431 950318.html

Castillo, R. \& Edwards, S. (2017) 'Spanish police raid Catalan government to halt banned referendum', Reuters, 1 of October, available online at:

https://www.reuters.com/article/us-spain-politics-catalonia/spanish-police-raid-catalangovernment-to-halt-banned-referendum-idUSKCN1BV0U0

Castro, I. (2019) 'Un sector del PSOE se levanta contra la decisión de Pedro Sánchez de aceptar un "'relator" para el diálogo en Catalunya', El Diario, 6 February, available online at: https://www.eldiario.es/politica/PSOE-decision-Pedro-Sánchez-

Catalunya 0 865113667.html

Cetrà, D., Casanas-Adam, E., \& Tàrrega, M. (2018). 'The 2017 Catalan independence referendum: A symposium', Scottish affairs, vol. 27, no. 1, pp. 126-143.

Colomer, J. M. (2020) 'Political Institutions in a Comparative Perspective', in Muro, D. \& Lago, I. The Oxford Handbook of Spanish Politics, Oxford: Oxford University Press.

Cordero, D. (2017) 'Puigdemont anuncia para el 1 de octubre el referéndum sobre la independencia', EI Pais, 9 June, available online at:

https://elpais.com/ccaa/2017/06/09/catalunya/1496992021 200661.html

Cordero, G., \& Montero, J. R. (2015). 'Against bipartyism, towards dealignment? The 2014 European election in Spain', South European Society and Politics, vol. 20 no. 3, pp. 357-379.

Cortizo, G. (2017) 'Fracasa la moción de censura contra Rajoy mientras Iglesias piensa ya en la siguiente', El Diario, 14 June, available online at:

https://www.eldiario.es/politica/Fracasa-censura-Rajoy-Iglesias-

siguiente 0 654434940.html

Cruz, M. (2018) ‘EI PSOE se dispara tras la llegada de Pedro Sánchez a La Moncloa, según el último barómetro del CIS', El Mundo, 2 August, available online at:

https://www.elmundo.es/espana/2018/08/02/5b62dda6268e3e43718b45f6.html

Cue, C. (2019) 'Pedro Sánchez convoca elecciones generales el 28 de abril', EL País, 15 February, available online at:

https://elpais.com/politica/2019/02/15/actualidad/1550216540 890788.html

Dalton, R.J. (2008) 'The Quantity and the Quality of Party Systems: Party System

Polarisation, Its measurement, and Its Consequences', Comparative Political Studies, vol. 41, no. 7, pp. 899-920.

Díez, A. (2017) 'Pedro Sánchez gana en todas las autonomías salvo Andalucía y Euskadi', El País, 22 May, available online at:

https://elpais.com/politica/2017/05/21/actualidad/1495402866 430403.html

De Diego, Sara (2015) 'La CUP comunica a Forcadell que no investirá a Artur Mas y exige "nombres nuevos"', El Confidencial, 4 November, available online at:

https://www.elconfidencial.com/espana/cataluna/2015-11-04/cup-carme-forcadellinvestidura-artur-mas 1083486/ 
Dinas, E. (2012). 'Left and right in the Basque Country and Catalonia: The meaning of ideology in a nationalist context', South European Society and Politics, vol. 17, no. 3, pp- 467-485.

Dominguez, I. and Albertola, M. (2017) ‘El Senado aprueba aplicar el artículo 155 en Cataluña', El País, 27 October, available online at:

https://elpais.com/politica/2017/10/27/actualidad/1509105725 777595.html

Downs, A. (1957). 'An economic theory of political action in a democracy', Journal of political economy, vol. 65, no. 2, pp. 135-150.

Esteban, P. (2019) 'Rivera ofrece a Casado un Gobierno de coalición "para echar a Sánchez" tras el 28-A', El Confidencia, 26 March, available online at: https://www.elconfidencial.com/elecciones-generales/2019-03-26/rivera-ofrece-casadogobierno-coalicion-elecciones-generales 1905550/

Evans, J. (2002) 'In defence of Sartori: Party system change, voter preference distributions and other competitive incentives', Party Politics, vol. 8, no. 2, pp. 155-174.

Falcó-Gimeno, A., \& Verge, T. (2013). 'Coalition Trading in Spain: Explaining Statewide Parties' Government Formation Strategies at the Regional Level', Regional \& Federal Studies, vol. 23, no. 4, pp. 387-405.

Fundación Alternativas (2018) Informe sobre el Estado de la Democracia, 2017, Madrid.

García, L.B (2016) 'Carles Puigdemont, investido 130 president de la Generalitat con el apoyo de la CUP', La Vanguardia, 11 January, available online at:

https://www.lavanguardia.com/politica/20160110/301314156969/carles-puigdemontpresidente-cataluna.html

García, L.B. (2018a) 'Quim Torra, investido presidente de la Generalitat, primer paso para levantar el 155', La Vanguardia, 14 May, available online at:

https://www.lavanguardia.com/politica/20180514/443579266437/quim-torra-presidentegeneralitat.html

García, L.B. (2018b) ‘El Gobierno celebrará el Consejo de Ministros del 21-D en la Llotja de Mar de Barcelona', La Vanguardia 12 December, available online at:

https://www.lavanguardia.com/politica/20181212/453520515398/consejo-de-ministrosIlotja-de-mar-21d-barcelona-gobierno.html

Galais, C., \& Serrano, I. (2019). The effects of regional attachment on ideological selfplacement: a comparative approach, Comparative European Politics, pp. 1-23.

Garea, F. (2017) 'Rajoy se asegura media legislatura al superar el escollo del Presupuesto', El País, 1 June, available online at:

https://elpais.com/politica/2017/05/31/actualidad/1496215228 873417.html

Gil, R. (2019) 'El Gobierno más breve de la democracia: así han sido los ocho meses de Pedro Sánchez', RTVE, 18 February, available online at:

http://www.rtve.es/noticias/20190215/gobierno-mas-breve-democracia-asi-han-sidoocho-meses-pedro-sanchez/1883875.shtml

Gonzalez, G. (2019) 'Ciudadanos desprecia la reunión PP-Vox: "No tenemos ni cabida ni interés"', El Mundo, 6 January, available online at:

https://www.elmundo.es/espana/2019/01/06/5c3111e2fc6c837e268b467d.html

Guinjoan, M. (2016). Parties, elections and electoral contests: Competition and contamination effects. Routledge: London. 
Hooghe, L., \& Marks, G. (2009). 'A postfunctionalist theory of European integration: From permissive consensus to constraining dissensus', British journal of political science, vol. 39, no. 1, pp. 1-23.

Hutter, S., Kriesi, H., \& Vidal, G. (2018). 'Old versus new politics: The political spaces in Southern Europe in times of crises', Party Politics, vol. 24, no. 1, pp. 10-22.

Infolibre (2016) 'EI PSOE asegura que no pactará con los independentistas para desalojar a Rajoy', 8 September, available online at:

https://www.infolibre.es/noticias/politica/2016/09/08/el psoe garantiza que pactara c on los independentistas busqueda una alternativa rajoy 54459 1012.html

Junquera, N. (2018) 'Pablo Casado vence en el congreso del PP y consuma el giro a la derecha', El País, 22 July, available online at:

https://elpais.com/politica/2018/07/21/actualidad/1532157539 615979.html

Junquera, N. (2019) 'Alivio en el PP al evitar el 'sorpasso', conservar Madrid y desalojar a Carmena', El País, 27 May, available online at:

https://elpais.com/politica/2019/05/26/actualidad/1558884920 187937.html

Kedar, O. (2005). 'When moderate voters prefer extreme parties: Policy balancing parliamentary elections', American Political Science Review, vol. 99, no.2, pp. 185-199.

Knutsen, O., \& Kumlin, S. (2005). Value orientations and Party Choice' cap. 6 in Jaques Thomassen (red.) The European Voter. A Comparative Study of Modern Democracies. Oxford: Oxford University Press.

Lachat, R. (2008) 'The Impact of Party Polarisation on ideological voting', Electoral Studies, vol. 27, no. 4, pp. 687-698.

Lamet, J. and Sanmartin, O.R. (2019) 'Casado pide a Vox que no se presente en 28 provincias', El País, 14 March, available online at:

https://www.elmundo.es/espana/2019/03/14/5c896129fdddffc65f8b4598.html

Limón, R. (2017) 'Pedro Sánchez oficializa su candidatura a la secretaría general del PSOE', EI País, 28 January, available online at:

https://elpais.com/politica/2017/01/28/actualidad/1485607288 759266.html

Linz, J. J., \& Montero, J. R. (1999). 'The party systems of Spain: Old cleavages and new challenges', Estudio/ Working Paper 1999/138, June 1999.

Luna, V. (2017) 'Susana Díaz se lanza como candidata exhibiendo músculo y tirando del PSOE histórico', 20 Minutos, 26 March, available online at:

https://www.20minutos.es/noticia/2995520/0/demostracion-fuerza-susana-diaz-viejaguardia-psoe-personas/\#xtor=AD-15\&xts=467263

Mainwaring, S., \& Zoco, E. (2007) 'Political sequences and the stabilization of interparty competition: electoral volatility in old and new democracies', Party politics, vol. 13, no.2, pp. 155-178.

Marcos, J. (2019) 'Sánchez pide el voto para el PSOE como "el único partido moderado"', El País, 14 April, available online at:

https://elpais.com/politica/2019/04/14/actualidad/1555239230 325572.html

Martin, P. (2018) 'ERC y el PDECAT valoran la oferta de diálogo de Sánchez pero mantienen la incógnita sobre su voto', El Periódico, 31 of May, available online at: https://www.elperiodico.com/es/politica/20180531/pdecat-erc-independentistasmocion-censura-pedro-sanchez-6849849 
Martín-Arroyo, J. (2018) 'Díaz convoca elecciones para evitar el desgaste del PSOE y la inestabilidad', El País, 9 October, available online at:

https://elpais.com/politica/2018/10/08/actualidad/1538995646 481936.html

Mateo, J.J. (2017) 'Ciudadanos elimina la socialdemocracia de su ideario y abraza el liberalismo progresista', El País, 4 February, available online at:

https://elpais.com/politica/2017/02/04/actualidad/1486205681 943757.html

Mayo, M.G. (2019) 'El Congreso tumba los Presupuestos de Pedro Sánchez’, Expansión, 1 February, available online at:

https://www.expansion.com/economia/2019/02/13/5c63c83f468aeb4d588b4576.html

Mudde, C. (2009). Populist radical right parties in Europe. Cambridge University Press: Cambridge.

Nieto, A. (2018) 'Sánchez intenta derribar a Rajoy con una moción de censura', El País, 26 May, available online at:

https://elpais.com/politica/2018/05/25/actualidad/1527273310 428019.html

Orriols, L., \& Cordero, G. (2016) 'The breakdown of the Spanish two-party system: the upsurge of Podemos and Ciudadanos in the 2015 general election', South European Society and Politics, vol. 21, no. 4, pp. 469-492.

Orriols, L., \& Rodon, T. (2016) 'The 2015 Catalan election: The independence bid at the polls', South European Society and Politics, vol. 21, no. 3, pp. 359-381.

Olmo, J. M. (2018) '20-S, crónica de un asedio: "Los más exaltados intentan acceder al edificio"', El Confidencial, 20 September 2018, available online at:

https://www.elconfidencial.com/espana/2018-09-20/20s-cronica-asedio-conselleriaeconomia 1618547/

PSOE (2017) 'Estatutos y Reglamentos', 17 April, available online at:

https://www.psoe.es/transparencia/informacion-politica-organizativa/estatutos-yreglamentos-federales/

PP (2018) 'Estatutos', 16 April, available online at:

http://www.pp.es/sites/default/files/documentos/estatutos xvii.pdf

Pardos-Prado, S., \& Dinas, E. (2010). 'Systemic polarisation and spatial voting', European Journal of Political Research, vol. 49, no. 6, pp. 759-786.

Pardo, I. (2019) 'Podemos se erige en "garantía" para que haya un Gobierno de izquierdas', La Vanguardia, 6 April, available at:

https://www.lavanguardia.com/politica/20190406/461482153694/podemos-garantiagobierno-izquierda-espana-pablo-iglesias-presos-politicos-psoe.html

Penadés, A. \& Santiuste, S. (2013) 'La desigualdad en el sistema electoral español y el premio a la localización del voto', Revista Española de Ciencia Política, vol. 32, pp. 89-116.

Pinar, C. (2019) 'Calvo asegura que el relator "no es un observador internacional" e insiste en una mesa solo de partidos catalanes', 20 Minutos, 6 February, available online at: https://www.20minutos.es/noticia/3555638/0/rueda-de-prensa-carmen-calvorelator-cataluna-gobierno/\#xtor=AD-15\&xts=467263

Pinheiro, M. (2017) 'La jueza decreta prisión incondicional para Junqueras y siete exconsellers', EL Diario, 2 November, available online at:

https://www.eldiario.es/politica/decreta-prision-incondicional-Junqueras-

consellers 0 703779702.html 
Pinheiro, M. and Barandela, M. (2019) 'EI CIS prevé una clara victoria de la izquierda el 26M: mantiene sus gobiernos y gana en la Comunidad de Madrid', EL Diario, 9 May, available online at: https://www.eldiario.es/politica/CIS-izquierda-

gobiernos 0 897310522.html

Puente, A. (2017) 'Puigdemont suspende la declaración de independencia para buscar el diálogo', El Diario, 10 October, available online at:

https://www.eldiario.es/catalunya/politica/Puigdemont-independencia-Catalunyamediacion-internacional 0 695730833.html

Quitian, S. (2018) ‘El Parlament rechaza la investidura de Jordi Turull tras la abstención de la CUP', La Vanguardia, 21 March, available online at:

https://www.lavanguardia.com/politica/20180322/441828264201/parlament-catalunyarechaza-investidura-jordi-turull-cup.html

Ramirez, D. (2019) 'Ciudadanos elige al PP como "socio preferente" sin negociar con Vox y no descarta al PSOE', El Español, 3 June, available online at:

https://www.elespanol.com/espana/politica/20190603/ciudadanos-pp-preferente-cierrapuerta-vox-no/403460089 0.html

Ramiro, L. (2016). 'Effects of party primaries on electoral performance: The Spanish Socialist primaries in local elections', Party Politics, no. 22, vol. 1, pp.125-136.

Ramos, M. \& Simón, P. (2015) '¿Qué pueden cambiar Podemos y Ciudadanos en el sistema de partidos', Zoom Político, https://www.fundacionalternativas.org/laspublicaciones/libros/que-pueden-cambiar-podemos-y-ciudadanos-en-el-sistema-departidos

Romero, A. (2018) 'Casado anuncia un rearme ideológico del partido desde "el orgullo del pasado"', ABC, 22 June, available online at: https://www.abc.es/espana/abcicasado-anuncia-rearme-ideologico-partido-desde-orgullo-pasado201807220240 noticia.html

Reyero, I. (2018) 'PP y Cs se quedan solos pidiendo en el Congreso que se active el 155', ABC, 17 October, available online at: https://www.abc.es/espana/abci-pp-yquedan-solos-pidiendo-congreso-active-155-201810170226 noticia.html

Riera, P. (2015). 'Economy, type of government, and strategic timing of elections: Calling opportunistic early elections in OECD democracies', West European Politics, vol. 38, no. 6, 1129-1151.

Rodríguez Teruel, J., \& Barrio, A. (2016). 'Going national: Ciudadanos from Catalonia to Spain', South European Society and Politics, vol. 21, no. 4, pp. 587-607.

Romero, J. (2017) ‘Pedro Sánchez arrolla a Susana Díaz 4 a 1 entre los votantes del PSOE', El Confidencial, 18 March, available online at:

https://www.elconfidencial.com/espana/2017-03-18/crisis-psoe-encuesta-dympreferencias-candidatos $1350827 /$

Sartori, G. (1976) Parties and party systems. New York: Cambridge University Press.

Sartori, G. (2005). Parties and party systems: A framework for analysis. Colchester: ECPR press.

Sanz, L.A. (2019) 'El economista Francisco de la Torre también dimite de la dirección de Ciudadanos por discrepancias con Rivera', El Mundo, 25 July, available online at: https://www.elmundo.es/espana/2019/07/25/5d39f5f5fc6c8374678b45e3.html

Sanz, L.A. and Sanmartin, O.R. (2019) 'Madrid estalla en un clamor contra "las cesiones al independentismo": "¡Elecciones ya!"', El Mundo, 10 February, available 
online at:

https://www.elmundo.es/espana/2019/02/10/5c6011b8fc6c83ab688b46b3.html

Sánchez-Cuenca, I., \& Dinas, E. (2012). 'Introduction: Voters and parties in the Spanish political space', South European Society and Politics, vol. 17, no. 3, pp. 365374.

Sánchez-Cuenca, I., \& Dinas, E. (2016). Voters and Parties in the Spanish Political Space. Routledge.

Salles, Q. (2017) 'Tengo el tupperware, ¿dónde quedamos?, así llegaron las urnas', La Vanguardia, 1 October, available online at:

https://www.lavanguardia.com/politica/20171001/431694312292/urnasreferendum.html

Santos, P. (2019) 'Ciudadanos veta cualquier pacto futuro con Sánchez para formar Gobierno', El Periódico, 13 February, available online at:

https://www.elperiodico.com/es/politica/20190213/rivera-veto-Sánchez-eleccionesmoncloa-7302100

Santos, P and Sierra, J.R. (2018) 'Spanish police raid Catalan government to halt banned referendum' El Periódico, 2 of October, available online at:

https://www.elperiodico.com/es/politica/20181002/rey-discurso-3o-dudas-gobiernorajoy-7066927

Sierra, J.R, and Marmol, I (2018) 'EI PNV apoya la moción de censura y abre la puerta de La Moncloa a Sánchez', El Periódico, 31 October, available online at:

https://www.elperiodico.com/es/politica/20180531/mocion-censura-pnv-6849718

Simón, P. (2016) 'The challenges of the new Spanish multipartism: government formation failure and the 2016 general election', South European Society and Politics, vol. 21, no. 4, pp. 493-517.

Tortosa, M.D. (2019) 'Juanma Moreno, elegido presidente con los votos del PP, Ciudadanos y Vox', Diario Sur, 17 January, available online at:

https://www.diariosur.es/andalucia/juanma-moreno-nuevo-20190116172145-nt.html

Turnbull-Dugarte, S. J. (2019) 'Explaining the end of Spanish exceptionalism and electoral support for Vox', Research \& Politics vol. 6, no.2, doi: 2053168019851680.

Usera, A. (2019) 'Vox confía en "dar la sorpresa" el domingo y "recuperar España"', La Opinión de Málaga, 15 April, available online at:

https://www.laopiniondemalaga.es/malaga/2019/04/25/vox-confia-recuperar-espana28/1084387.html

Varela, F. (2018) 'Sánchez y Torra acuerdan avanzar en una "respuesta democrática" a las demandas catalanas que respete "la seguridad jurídica"', Infolibre, 20 December, available online at:

https://www.infolibre.es/noticias/politica/2018/12/20/Sánchez torra acuerdan avanzar una respuesta democratica las demandas catalanas que respete seguridad jurid ica $901401012 . \mathrm{html}$ 